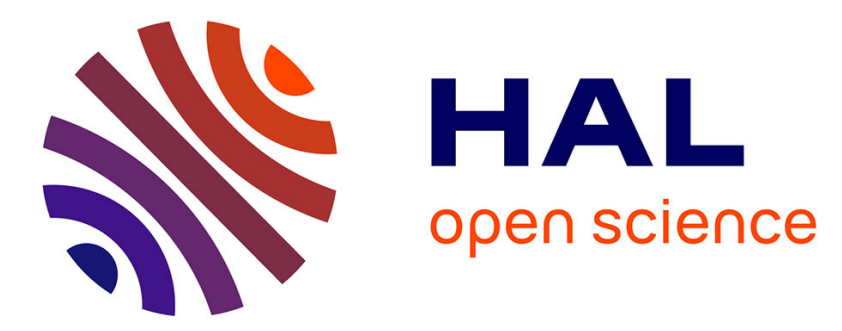

\title{
Crystal structure, spectroscopic and biological study of a new inorganic-organic hybrid compound [Cd4Cl12(H2O)2]n (C10N4H28)n
}

\author{
A. Hachani, I. Dridi, S. Elleuch, T. Roisnel, R. Kefi
}

\section{- To cite this version:}

A. Hachani, I. Dridi, S. Elleuch, T. Roisnel, R. Kefi. Crystal structure, spectroscopic and biological study of a new inorganic-organic hybrid compound $[\mathrm{Cd} 4 \mathrm{Cl} 12(\mathrm{H} 2 \mathrm{O}) 2] \mathrm{n}(\mathrm{C} 10 \mathrm{~N} 4 \mathrm{H} 28) \mathrm{n}$. Inorganic Chemistry Communications, 2019, 100, pp.134-143. 10.1016/j.inoche.2018.12.006 . hal-02043043

HAL Id: hal-02043043

https://hal-univ-rennes1.archives-ouvertes.fr/hal-02043043

Submitted on 28 Mar 2019

HAL is a multi-disciplinary open access archive for the deposit and dissemination of scientific research documents, whether they are published or not. The documents may come from teaching and research institutions in France or abroad, or from public or private research centers.
L'archive ouverte pluridisciplinaire HAL, est destinée au dépôt et à la diffusion de documents scientifiques de niveau recherche, publiés ou non, émanant des établissements d'enseignement et de recherche français ou étrangers, des laboratoires publics ou privés. 


\title{
Crystal structure, spectroscopic and biological study of a new inorganic- organic hybrid compound $\left[\mathrm{Cd}_{4} \mathrm{Cl}_{12}\left(\mathrm{H}_{2} \mathrm{O}\right)_{2}\right]_{n}\left(\mathrm{C}_{10} \mathrm{~N}_{4} \mathrm{H}_{28}\right)_{n}$
}

\author{
Aroussia Hachani ${ }^{[a]}$, Imen Dridi ${ }^{[b]}$, Slim Elleuch ${ }^{[c]}$, Thierry Roisnel ${ }^{[\mathrm{d}]}$, Riadh Kefi ${ }^{[\mathrm{a}] *}$ \\ ${ }^{a}$ Laboratoire de Chimie des Matériaux, Faculté des Sciences de Bizerte, 7021 Zarzouna, Tunisie. \\ ${ }^{b}$ Laboratory of Biochemistry and Molecular Biology, Faculty of Sciences, Risks Related to \\ Environmental Stress, Struggle and Prevention (UR17ES20), University of Carthage, The Ministry \\ of Higher Education and Scientifc Research, Zarzouna, 7003 Bizerte, Tunisia. \\ ${ }^{c}$ Laboratoire de Physique Appliquée, Faculté des Sciences de Sfax, Université de Sfax, B.P. 1171, \\ 3000 Sfax, Tunisia \\ ${ }^{\mathrm{d}}$ Centre de Diffractométrie X, UMR 6226 CNRS, Institut Sciences Chimiques de Rennes, \\ Université de Rennes I, 263 Avenue du, Général Leclerc, 35042 Renne, France.
}

\begin{abstract}
A new organic-inorganic hybrid compound $\left[\mathrm{Cd}_{4} \mathrm{Cl}_{12}\left(\mathrm{H}_{2} \mathrm{O}\right)_{2}\right] n\left(\mathrm{C}_{10} \mathrm{~N}_{4} \mathrm{H}_{28}\right) n$ has prepared with [1,4-Bis(3-aminopropyl)piperazine $\left.=\mathrm{C}_{10} \mathrm{~N}_{4} \mathrm{H}_{28}\right]$ and it was characterized by single crystal X-ray diffraction, spectroscopy measurement, DTA-TG measurement, photoluminescence properties, and biological analysis. It crystallizes in the monoclinic system with the space group of $\mathrm{P} 2_{1} / \mathrm{n}$ with the following unit cell parameters: $\mathrm{a}=9.5808(17), \mathrm{b}=$ 9.8438(18), $\mathrm{c}=16.050(3) \AA, \beta=93.142(6)^{\circ}, \mathrm{V}=1511.4(5)$ and $\mathrm{Z}=2$. The atomic arrangement can be described as an infinite one-dimensional coordination polymeric doublechain running along the crystallographic b-axis, those chains are interconnected by water molecules via $\mathrm{O}-\mathrm{H}$...Cl hydrogen bonds to form layers parallel to (101) plane, between those layer interconnected the organic cations to performed an infinities three dimensional network. The Hirshfeld surfaces and fingerprint plots are used for decoding of the nature and proportion of contacts in the crystal packing. The vibrational properties were investigated experimentally by means of IR spectroscopy and theoretically by DFT calculations on the organic cation. Also the optical absorption and photoluminescence properties of the compound were achieved at room temperature in the solid state. The bioassay results showed
\end{abstract}


that the structure exhibits significant antibacterial activity. Finaly, thermogravimetric analysis shows that this compound is stable until $250 \mathrm{C}^{\circ}$.

Keywords: organic-inorganic hybrid, X-ray diffraction, double-chains, Hirshfeld surface, Infrared, UV-Vis spectroscopy, DFT calculations, antioxidant activity, antibacterial activity and thermal analysis (TG/DTA).

\section{Introduction}

The field of the hybrid material synthesis widened from up to date day because of their functional properties are various like, photoluminescence, properties magnetic, ferromagnetic and electric [1-9]. These hybrid materials have chemical and physical properties are very interesting because of the combination of the properties on the one hand inorganic component and on the other they share of the organic molecular component within one scale [10]. Beyond the molecular vision, where the atoms combine to form already complex structures, there exists another field of association which implies this time of the molecules to give assemblies to the multiple applications. This field of studies implies the interactions between the components constituting the crystalline compounds. Such interactions include van der Waals interactions, electrostatic interactions, hydrogen bonding. In this area, polynuclear d10metal complexes have been found to exhibit important structural and photoluminescent properties [11].

Piperazine derivatives have a broad range of applications in pharmaceuticals as antimalarial [12], antituberculosis [13], antitumor [14], anticancer [15] and antiviral [16] agents. The piperazine nucleus was noted as a favored structure because it is able to bind to the multiple receptors with high affinity. In the last decade, a number of piperazine derivatives have been synthesized and evaluated for their cytotoxic activity [17]. The piperazine nucleus is frequently found in biologically active compounds across a number of different therapeutic areas [18]. Some of these therapeutic areas include antimicrobial, antitubercular, anticonvulsant, antidepressant, anti-inflammatory, cytotoxic, antimalarial, antiarrhythmic, antioxidant and antiviral activities etc. [19].

\section{Experimental}

\subsection{Chemical preparation}

The solution of $\left(\mathrm{CdCl}_{2}\right) .5 \mathrm{H}_{2} \mathrm{O}(48.6 \mathrm{mg}, 0.4 \mathrm{mmol})$ was added to a solution 1,4-Bis(3aminopropyl)piperazine $(11 \mathrm{mg}, 0.1 \mathrm{mmol})$ in water together with five drops of concentrated 
hydrochloric acid. After continuously stirring for $7 \mathrm{~h}$, the resultant solution allowed to evaporate at room temperature. Crystals $\left[\mathrm{Cd}_{4} \mathrm{Cl}_{12}\left(\mathrm{H}_{2} \mathrm{O}\right)_{2}\right] \mathrm{n}\left(\mathrm{C}_{10} \mathrm{~N}_{4} \mathrm{H}_{28}\right)_{\mathrm{n}}$, which remind stable under normal condition of temperature and humidity, were isolated after a week and subjected to X-ray diffraction analysis.

\subsubsection{X-ray single crystal structural analysis}

A single crystal was carefully selected under a microscope in order to perform its structural analysis by X-ray diffraction. Data were collected at $150 \mathrm{~K}$ on a D8 VENTURE Bruker AXS diffractometer using a mirror monochromated Mo K $\alpha$ radiation, $\lambda=0.71073 \AA$. The structure was solved by dual-space algorithm using the SHELXT program [20], and then refined with full-matrix least-square methods based on F2 (SHELXL) [21]. All non-hydrogen atoms were refined with anisotropic atomic displacement parameters. Except nitrogen and water molecule linked hydrogen atoms that were introduced in the structural model through Fourier difference maps analysis, $\mathrm{H}$ atoms were finally included in their calculated positions. A final refinement on F2 with 3453 unique intensities and 164 parameters converged at $\omega \mathrm{R}(\mathrm{F} 2)=0.0702(\mathrm{R}(\mathrm{F})=0.0278)$ for 3312 observed reflections with $\mathrm{I}>2 \sigma(\mathrm{I})$. Crystal data are reported in (Table 1). Drawings were made with Diamonds [22].

\subsubsection{IR spectroscopy}

Fourier Transform Infrared (FTIR) spectra of powder samples were obtained using a Nicolet 1000 spectrophotometer. The scanning range was $4000-400 \mathrm{~cm}^{-1}$.

\subsubsection{UV spectroscopy}

Solid-state electronic and diffuse reflectance spectra were recorded at room temperature with Perkin Elmer Lamda35 UV/Vis spectrophotometer in the wavelength of 200-700 nm.

\subsubsection{Photoluminescence}

Emission spectrum was obtained on a Perkin-Elmer LS55 fluorescence spectrometer equipped with a $450 \mathrm{~W}$ xenon lamp as the excitation source using solid sample at room temperature.

\subsubsection{In vitro antioxidant activity}

To access the antioxidant activity of $\left[\mathrm{Cd}_{4} \mathrm{Cl}_{12}\left(\mathrm{H}_{2} \mathrm{O}\right)_{2}\right] \mathrm{n}\left(\mathrm{C}_{10} \mathrm{~N}_{4} \mathrm{H}_{28}\right) \mathrm{n}$, two tests DPPH and ABTS were performed. Ascorbic acid was used as positive control for both of the test.

\subsubsection{DPPH radical scavenging activity}

The assay is based on the measurement of the scavenging capacity of antioxidants towards the stable free radical 1,1-diphenyl-2-picrylhydrazil, which presents a deep purple 
color and an absorption band in the range of 515-520 $\mathrm{nm}$. The odd electron of nitrogen atom in DPPH is reduced by receiving a hydrogen atom from antioxidants to be converted to a more stable DPPH molecule. Taking into account that the reduced form of DPPH have a pale yellow color, it is possible to determine the antioxidant activity of a compound by studying the color change by spectrophotometry. The results are normally expressed as inhibitory concentration (IC50), which is defined as the concentration of antioxidant reducing the free radical DPPH about 50\%).

For studying DPPH radical scavenging activity $100 \mu \mathrm{l}$ of $\left[\mathrm{Cd}_{4} \mathrm{Cl}_{12}\left(\mathrm{H}_{2} \mathrm{O}\right)_{2}\right] \mathrm{n}\left(\mathrm{C}_{10} \mathrm{~N}_{4} \mathrm{H}_{28}\right) \mathrm{n}$ methanolic solution at different concentrations $(0.1-25 \mathrm{mg} / \mathrm{ml})$ was added to $3 \mathrm{ml}$ of DPPH solution $(0.1 \mathrm{mM})$ prepared on methanol. The mixture reaction was incubated for $30 \mathrm{~min}$. the absorbance was accessed at $517 \mathrm{~nm}$ [23]. The scavenging activity was accessed by the following formula: DPPH radicals scavenged activity $(\%)=\left[\left(\mathrm{A}_{0}-\mathrm{A}_{1}\right) / \mathrm{A}_{0}\right] \times 100$.

Where $A_{0}$ is the absorbance of the blank and $A_{1}$ is the absorbance measured in the presence of the tested compound.

The results were expressed as the concentration of $\left[\mathrm{Cd}_{4} \mathrm{Cl}_{12}\left(\mathrm{H}_{2} \mathrm{O}\right)_{2}\right] \mathrm{n}\left(\mathrm{C}_{10} \mathrm{~N}_{4} \mathrm{H}_{28}\right) \mathrm{n}$ that scavenged $50 \%$ of the free radicals from the reaction mixture. Measurements were performed in triplicate, and the presented results are the arithmetic means of the measurements \pm SEM.

\subsubsection{ABTS radical scavenging activity}

ABTS is stable, however it is able to react energetically with donating hydrogen atoms or electrons molecules. ABTS assay was done according to the method of [24]. The ABTS stock solution was prepared by reacting $2.45 \mathrm{mM}$ potassium persulphate and $7 \mathrm{mM}$ ABTS (2,2'azinobis(3-ethylbenzothiazoline-6-sulfonic acid)). The mixture was incubated in the dark for $12-16 \mathrm{~h}$ at room temperature.

The working solution was freshly prepared by mixing equal volume of the stock solution and methanol. Free radical scavenging activity was determined by mixing $300 \mu 1$ of the compound solution at various concentrations with $3 \mathrm{ml}$ of ABTS working solution. The absorbance was measured at $734 \mathrm{~nm}$, after the incubation of the reaction mixture, for $6 \mathrm{~min}$, at room temperature. The scavenging activity was calculated based on the following formula: ABTS radicals scavenged activity $(\%)=\left[\left(\mathrm{A}_{0}-\mathrm{A}_{1)} / \mathrm{A}_{0}\right] \times 100\right.$. Where $\mathrm{A}_{0}$ is the absorbance of the blank (the reaction mixture without the tested compound) and $A_{1}$ is the absorbance measured 
in the presence of the tested compound. Measurements were performed twice in triplicate, and results are presented as the arithmetic means of the measurements \pm SEM.

\subsubsection{Determination of in-vitro antibacterial activity by paper disc diffusion method}

Antibacterial activity of $\left[\mathrm{Cd}_{4} \mathrm{Cl}_{12}\left(\mathrm{H}_{2} \mathrm{O}\right)_{2}\right] \mathrm{n} \quad\left(\mathrm{C}_{10} \mathrm{~N}_{4} \mathrm{H}_{28}\right) \mathrm{n}$ methanolic solution was assessed by the paper disc diffusion method, against 5 bacteria including two gram-positive bacteria, namely Enterococcus faecalis ATCC 29212 and Staphylococcus aureus NCTC 6571 and three gram-negative bacteria, namely Pseudomonas aeruginosa SH 38, Escherichia coli JW 1772 and Salmonella typhimurium ATCC 14028.

For the paper disc diffusion method, $200 \mu 1$ of each tested bacteria suspension, containing $10^{6}$ colony-forming units (cfu/ml), was used for inoculating the plates. Sterile discs (Whatman filter paper), having $6 \mathrm{~mm}$ of diameter were soaked with $20 \mu \mathrm{l}$ of $\left[\mathrm{Cd}_{4} \mathrm{Cl}_{12}\left(\mathrm{H}_{2} \mathrm{O}\right)_{2}\right] \mathrm{n}$ $\left(\mathrm{C}_{10} \mathrm{~N}_{4} \mathrm{H}_{28}\right) \mathrm{n}$ methanolic solution $(1 \mathrm{mg} / \mathrm{ml})$. Impregnated discs were then dried for $2 \mathrm{H}$ and placed on inoculated plates. The seeded plates were, then, incubated for $24 \mathrm{~h}$ at $37^{\circ} \mathrm{C}$. The inhibition's zones diameters were measured in millimeters. Each test was performed twice in triplicate.

\subsubsection{Thermal Analysis}

The thermogravimetric (TGA) and differential thermal analyses (DTA) were coupled using TG Labsys instrument. The powder sample $(9.3 \mathrm{mg})$ was heated rate from $100 \mathrm{C}^{\circ}$ and reaching $700 \mathrm{C}^{\circ}$ using a heating rate of $5 \mathrm{C}^{\circ} \cdot \mathrm{min}^{-1}$ under argan atmosphere.

\section{Results and discussion}

\subsection{Structure description}

As shown in (Fig.1), all the cadmium ions are octahedrally coordinated. The Cd1 cation is coordinated to six chlorine atoms, while the $\mathrm{Cd} 2$ cation is surrounded by five chlorine atoms and one water coordination molecule. The organic groups $\left[\mathrm{C}_{10} \mathrm{~N}_{4} \mathrm{H}_{28}\right]^{4+}$ tetracation does not participate in coordination to the metal atom, but forms ionic and hydrogen-bonded $(\mathrm{N}-$ $\mathrm{H} \ldots \mathrm{Cl}$ and $\mathrm{C}-\mathrm{H} . . \mathrm{Cl})$ contacts with the inorganic layers $\left[\mathrm{Cd}_{4} \mathrm{Cl}_{12}\left(\mathrm{H}_{2} \mathrm{O}\right)_{2}\right]_{\mathrm{n}}{ }^{4-}$ ion to perform an infinite three dimensional network (Fig.2). Packing of $\left[\mathrm{Cd}_{4} \mathrm{Cl}_{12}\left(\mathrm{H}_{2} \mathrm{O}\right)_{2}\right] n\left(\mathrm{C}_{10} \mathrm{~N}_{4} \mathrm{H}_{28}\right) n$ (Fig.3), shows an octahedron, within a unit of one $\left[\mathrm{CdCl}_{5}\left(\mathrm{H}_{2} \mathrm{O}\right)\right]$ and one $\left[\mathrm{CdCl}_{6}\right]$ octahedron, shares three cis-edges to form a tetramer of $\left[\mathrm{Cd}_{4} \mathrm{Cl}_{12}\left(\mathrm{H}_{2} \mathrm{O}\right)_{2}\right]$ that to form $\left[\mathrm{Cd}_{4} \mathrm{Cl}_{10}\left(\mathrm{Cl}_{4}\right)_{0,5}\left(\mathrm{H}_{2} \mathrm{O}\right)_{2}\right]_{n}{ }^{4-}$ inorganic anions (Fig.2). The negative charge of this anion is compensated by the organic tetracation, and bridging each other by two chlorine atoms ( $\mathrm{Cl} 4$ and $\left.\mathrm{Cl} 4^{\mathrm{iii}}\right)$ (iii: $-\mathrm{x}+1,-\mathrm{y}+2$, $-z^{+1)}$ to generate an infinite one-dimensional coordination polymeric double-chain running 
along the crystallographic b-axis. Like this the infinite anions double-chains were formed, by sharing on the one hand the chlorides of the square plan, and on the second hand they were linked by the axial chlorides (Fig.3). Both types of bonds formed the tetrahedral empty sites between the octahedral environments in the same double-chain.

The $\mathrm{Cd}-\mathrm{Cd}$ shortest distances within the chain, $\mathrm{Cd} 1-\mathrm{Cd} 2=3.773(1) \AA$, is fairly close to those reported in the case of one-dimensional chain of slightly distorted edge-sharing octahedra [25]. The chains are interconnected by water molecules via $\mathrm{O}-\mathrm{H} \cdots \mathrm{Cl}$ hydrogen bonds to form layers parallel to (101) plane (Fig.2). The organic cation and the inorganic anion are held together by hydrogen bonds $\mathrm{N}-\mathrm{H} . . . \mathrm{Cl}$, at one side of the aminic hydrogens and chlorides $\mathrm{Cl1}$, $\mathrm{Cl} 4$ and $\mathrm{Cl} 5$ of two adjacent tetramer chains, and on the other hand, the same interaction but with another inorganic layer. In the structure, a weak non classical C-H...Cl hydrogen bonding [26-30] is found to stabilize this edifice of about $2.68 \AA$ with the H4B...Cl3 (Fig. 2, Table 2).

In the title compound, the values of the $\mathrm{Cd}-\mathrm{Cl}$ bond lengths vary between 2.5293 (7) and 2.7934 (7) $\AA$, the $\mathrm{Cl}-\mathrm{Cd}-\mathrm{Cl}$ angles range from 82.23 (2) to 101.78 (2) ${ }^{\circ}$ (Table 6). These geometrical parameters agree with those found in $\mathrm{Cd}_{4} \mathrm{Cl}_{10}\left(\mathrm{C}_{6} \mathrm{H}_{14} \mathrm{NO}\right)_{2} \cdot 2 \mathrm{H}_{2} \mathrm{O}$, In this structure there are also two types of octahedron $\left(\mathrm{CdCl}_{6}\right.$ and $\left.\mathrm{CdCl}_{5} \mathrm{O}\right)$ with the $\mathrm{Cd}-\mathrm{Cl}$ distances are between 2.4887 (6) and 2.7517 (6) $\AA$ and the $\mathrm{Cl}-\mathrm{Cd}-\mathrm{Cl}$ angles ranging from 82.01 (2) to $100.38(2)^{\circ}[31]$, But in this structure the coordinating oxygen atom does not derive from a molecule of water, but from the organic molecule in the same way as the mondontate. The Cd...Cd separations of adjacent octahedral varies from 3.773(1) to 3.792(1) $\AA$. These distances are considerably longer than the values of about $3.36 \AA$ in the linear chain structures and close to those found in a double-chain structure.

All bond distances and angles within the $\left[\mathrm{C}_{10} \mathrm{~N}_{4} \mathrm{H}_{28}\right]^{4+}$ ion are in good agreement with those of another complex containing the same tetracation [32].

\subsection{Hirshfeld surface}

Hirshfeld surface analysis serves as a powerful tool for gaining additional insight into the intermolecular interaction of molecular crystals. The size and shape of Hirshfeld surface allows the qualitative and quantitative investigation and visualization of intermolecular close contacts in molecular crystals [33-34]. Hirshfeld surfaces and their related fingerprint plots are generated using the program Crystal Explorer. The crystallographic information file (.CIF) is given as input to the Crystal Explorer3.0 [35]. Also, an isosurface is obtained, and for each 
point of the isosurface two distances can be characterized: de, the distance from the point to the nigh atom extreme to the surface, and di, the distance to the nearby atom internal to the surface. Furthermore, the identification of the regions of particular importance to intermolecular interactions is obtained by mapping normalized contact distance $\left(\mathrm{d}_{\text {norm }}\right)$, expressed as: $\mathrm{d}_{\text {norm }}=\left(\mathrm{d}_{\mathrm{i}}-\mathrm{r}_{\mathrm{i}}^{\mathrm{vdw}}\right) / \mathrm{r}_{\mathrm{i}}^{\mathrm{vdw}}+\left(\mathrm{d}_{\mathrm{e}}-\mathrm{r}_{\mathrm{e}}^{\mathrm{vdw}}\right) / \mathrm{r}_{\mathrm{e}}^{\mathrm{vdw}}$; where $\mathrm{r}_{\mathrm{i}}^{\mathrm{vdw}}$ and $\mathrm{r}_{\mathrm{e}}{ }^{\mathrm{vdw}}$ are the van der Waals radii of the atoms.

Another way to represent the Hirshfeld surfaces [36] is to generate a representation that involves normalized contact distances taking into account the van der Waals radius of the atoms involved in the analysis. This way of portraying the surface is named $\mathrm{d}_{\text {orm }}$, this property is constituted by summation of the normalized contribution of de and di in relation to the van der Waals radius of the atoms involved in the expression. More concretely, this type of analysis makes it possible to graphically illustrate the relative positioning of the neighboring atoms belonging to molecules interacting together. Again, a color gradient is used to quantify the interactions taking place between the atoms within the crystal being studied. This gradient varies from blue to red through white. By considering intermolecular interactions, the bluish domains indicate that the distance separating neighboring atoms exceeds the sum of their respective van der Waals radii. The white areas mark the places where the distance separating the neighboring atoms is close to the sum of the van der Waals radius of the considered atoms. The red color is used to represent the places where there is interpenetration of the van der Waals rays of neighboring atoms. From these facts, it is appropriate to suspect the presence of non-covalent interactions between the atoms (or group of atoms) located at the interface of the zones represented in red which show a significant approximation between these atoms. The situation is more delicate when the domains considered are depicted in white, given the distance of the neighboring atoms which is at the limit of the sum of the van der Waals rays. Bluish areas illustrate areas where neighboring atoms are too far apart to interact with one another.

The enrichment ratios of contacts between the different chemical species were computed with software MoProViewer [37], in order to highlight which contacts are statistically favored and are maintaining the crystal packing. Enrichment ratios larger than unity denote contacts which are over-represented in the crystal packing with respect to the chemical composition on the Hirshfeld surface. The hydrophobic Hc atoms bound to carbon were distinguished from the more electropositive $\mathrm{H}-\mathrm{N}$ and $\mathrm{H}-\mathrm{O}$ hydrogen atoms (Hno) and 
reciprocal contacts $\mathrm{XY}$ and $\mathrm{YX}$ were merged. The chemical nature of contacts in the crystal structure is shown in Table 3.

The molecular Hirshfeld surfaces of the title compound were generated using a standard (high) surface resolution with the 3D d norm surfaces, the distance to the nearest nucleus inside the surface "di" and the distance to the nearest atoms outside "de", shape index and curvedness mapped over a fixed color scale of -1.109 (red) to $1.189 \AA$ (blue), from 0.758 to $2.642 \AA$ and 0.757 to $2.596 \AA,-1$ to $1 \AA$ and -4 to $4.04 \AA$, respectively (Fig.4). The 2D fingerprint maps of $\left[\mathrm{Cd}_{4} \mathrm{Cl}_{12}\left(\mathrm{H}_{2} \mathrm{O}\right)_{2}\right] \mathrm{n}\left(\mathrm{C}_{10} \mathrm{~N}_{4} \mathrm{H}_{28}\right)$ n provide some quantitative information about the individual contribution of the intermolecular interaction in the asymmetric unit (Fig.5). Globally, $\mathrm{H} \cdots \mathrm{Cl} / \mathrm{Cl} \cdots \mathrm{H}, \mathrm{H} \cdots \mathrm{H}$ and $\mathrm{Cd} \cdots \mathrm{Cl} / \mathrm{Cl} \cdots \mathrm{Cd}$ intermolecular interactions were most abundant in the crystal packing $\left(55.8,22.6,11.7 \%\right.$ respectively). The $d_{e}(y$ axis $)$ and $d_{i}(x$ axis) represent respectively the nearest internal and external distances ( $\left(\AA^{)}\right.$from using points on the Hirshfeld surface contacts (Fig.4). The contribution of the $\mathrm{Cl} \ldots \mathrm{H} / \mathrm{H} \quad \ldots \mathrm{Cl}$ intermolecular interactions for the crystal structure cohesion amounts to $55.8 \%$ and these contacts are attributed to $\mathrm{C}-\mathrm{H} . . . \mathrm{Cl}, \mathrm{N}-\mathrm{H} . . . \mathrm{Cl}$ and $\mathrm{O}-\mathrm{H}$... $\mathrm{Cl}$ hydrogen bonding interactions and appear as two shap symmetric spikes (1) in the two- dimensional fingerprint maps with a prominent long spike at $\mathrm{d}_{\mathrm{e}}+\mathrm{d}_{\mathrm{i}} \sim 2.6 \AA$. They have the important significant contribution to the total Hirshfeld surface $(55.8 \%)$ and this type appear with elevated enrichment $\mathrm{E}_{\mathrm{Cl} \ldots \mathrm{H}}=1.92$. Then the chlorine and hydrogen atoms are often mutual partners in the crystal contacts and they are electrostatically favorable due to the partial positive charge of $\mathrm{H}$ atoms. Furthermore, this type of contacts is important frequent interactions due to the abundance of chlorine and hydrogen on the molecular surface $\left(\% \quad \mathrm{~S}_{\mathrm{Cl}}=44.26\right.$ and $\left.\% \mathrm{~S}_{\mathrm{H}}=41.95\right)$ (Table 3). The $\mathrm{Cd}$... $\mathrm{Cl} / \mathrm{Cl}$...Cd interactions are the second most frequent interactions, this interactions covers $11.7 \%$ of the total surface and present in the middle of the scattered points in the twodimensional fingerprint maps with a single broad peak at $\mathrm{d}_{\mathrm{e}}=\mathrm{d}_{\mathrm{i}} \sim 1.3 \AA$, and this type appear with enrichment $\mathrm{E}_{\mathrm{Cd} \ldots \mathrm{Cl}}=1.53$. Also the $\mathrm{H} . . . \mathrm{H}$ contacts shows the presence of scattered points in the middle of the two-dimensional fingerprint maps with a single board peak respectively at $\mathrm{d}_{\mathrm{e}}=\mathrm{d}_{\mathrm{i}} \sim 1.4 \AA$ and which represent $22.6 \%$. These contacts are impoverished in the crystal with a value of enrichment equal to 0.53 . Finally, the three types of contacts present the stability of the crystal structure and the $\mathrm{Cl}$...H is the driving forces in the molecular arrangement.

It is evident that van der Waals forces exert an important influence on the stabilization of the packing in the crystal structure, other intercontacts, i.e. $\mathrm{Cl} \cdots \mathrm{Cl}(4.4 \%), \mathrm{C} \ldots \mathrm{C}(1.8 \%)$, $\mathrm{H} \ldots \mathrm{O} / \mathrm{O} \ldots \mathrm{H}(2.2 \%), \mathrm{C} \cdots \mathrm{H} / \mathrm{H} \cdots \mathrm{C}(0.9 \%), \mathrm{Cd} \cdots \mathrm{H} / \mathrm{H} \cdots \mathrm{Cd}(0.5, \%)$, and $\mathrm{N} \ldots \mathrm{C} / \mathrm{C} \ldots \mathrm{N}(0.1 \%)$ 
contribute less to the Hirshfeld surfaces. So, the relative contributions of the various interactions to the Hirshfeld surfaces were also calculated for the title compound (Fig.6).

The title compound contains $25.58 \% \mathrm{Hc}, 16.37 \% \mathrm{Hno}$ and $44.26 \% \mathrm{Cl}$ on the molecular surface. The self-contacts between charged species $\left(\mathrm{Cd}^{++}, \mathrm{O}^{\delta-}\right.$ and $\left.\mathrm{Hno}^{\delta+}\right)$ have enrichment $\mathrm{E}_{\mathrm{XX}}$ values lower than unity and are systematically avoided. The null values of the enrichment $\mathrm{Hn} / \mathrm{o} . . . \mathrm{N}$ and $\mathrm{Hn} / \mathrm{o}$... O proves well the absence of hydrogen bonding of which the atoms of oxygen and nitrogen are receivers (Table 3$). \mathrm{Cl}^{-} \ldots \mathrm{Cd}^{++}$ionic bridges are very favored $(E=1.72)$. All Exx values associated to contacts with the same chemical species (diagonal elements in Table 3) are impoverished, except for carbon atoms. The C...C contacts betwen the cationic molecules, represent only $2.3 \%$ of the hirshfeld surface, but they are extremely enriched (enrichment Ecc=11.34), while the $\mathrm{O} \ldots \mathrm{C}$ contacts does not have enrichment. The N...C interactions show a very high enrichment equal to 7.46 and refer to interactions between the organic cations.

\subsection{IR spectroscopy}

FTIR spectroscopy was used to verify the functional groups present in the crystal and to investigate their vibrational behavior in the solid state. The experimental IR spectrum of the title crystalline complex and corresponding simulated spectrum of the organic cation are superimposed in S.1. The assignment of the characteristic vibrational modes of this compound is mainly based on the theoretical results and on comparison with similar materials [38-40]. In the high frequency domain, the IR spectrum is decomposed in three well separated bands. The first, centered at $3435 \mathrm{~cm}^{-1}$, do not appear in the simulated spectrum and corresponds to the stretching mode of the $\mathrm{H}_{2} \mathrm{O}$ molecule. The most intense is between 2850 and $3200 \mathrm{~cm}^{-1}$ and is related to $\mathrm{NH}$ and $\mathrm{NH}_{3}$ stretching. The later band centered at $2770 \mathrm{~cm}^{-1}$ attributed to the $\mathrm{CH}_{2}$ groups stretching. The bands observed in the range of $1800-2500 \mathrm{~cm}^{-1}$ are attributed to the harmonic combination bands. At lower frequency range, the bands observed at 1602 and 1496 $\mathrm{cm}^{-1}$ are ascribed to $\mathrm{NH}_{3}$ asymmetric and symmetric deformation modes, respectively, while deformation mode of the $\mathrm{CH}_{2}$ groups are assigned to the large band between 1200 and 1450 $\mathrm{cm}^{-1}$. The deformation of $\mathrm{N}-\mathrm{H}$ is assigned to the band at $1160 \mathrm{~cm}^{-1}$ and the stretching modes of the C-C and C-N bonds are observed at 1000 and $941 \mathrm{~cm}^{-1}$, respectively. Finally, the series of bands observed from 900 to $400 \mathrm{~cm}^{-1}$ are assigned to the deformation of C-C-C, C-C-N and $\mathrm{C}-\mathrm{N}-\mathrm{C}$ in the organic skeleton.

It is worthily noting the relative good agreement observed between the theoretical and experimental IR spectra. Good correlation between almost all the vibrational features is 
detected and well proved by the calculated correlation coefficient 0.9723 computed in the correlation graph shown in Fig. 7.

\subsection{Optical Absorption and photoluminescence}

The solid state UV-Vis spectrum of crystalline $\left[\mathrm{Cd}_{4} \mathrm{Cl}_{12}\left(\mathrm{H}_{2} \mathrm{O}\right)_{2}\right]_{\mathrm{n}}\left(\mathrm{C}_{10} \mathrm{~N}_{4} \mathrm{H}_{28}\right)_{\mathrm{n}}$, measured at room temperature is shown in Fig.8. The absorption spectrum exhibits two distinct absorption bands centered at 290 and $414 \mathrm{~nm}$. This is very similar to that observed for other previously reported chloro-cadmate based hybrid materials [38, 41]. Here, since we used a simple organic molecule transparent in the visible region, we are then brought to attribute the observed optical absorption features to the transitions within the inorganic part.

The minimum energy absorption peak at $414 \mathrm{~nm}\left(2.99 \mathrm{eV}, 24.154 \mathrm{~cm}^{-1}, \varepsilon_{\max }=34.5 \mathrm{M}^{-1}\right.$ $\mathrm{cm}^{-1}$ ) is mainly due to the band gap absorption and it is assigned to the excitation of free electron-hole pairs within the $\left[\mathrm{CdCl}_{6}\right]^{2-}$ octahedron. This band-to-band absorption is characterized by the transition from the top of the valence band consisting of $\mathrm{Cl}(3 \mathrm{p})$ orbital to the bottom of the $\mathrm{Cd}(5 \mathrm{~s})$ conduction band. The maximum energy absorption peak at $290 \mathrm{~nm}$ (4.27 eV, $34.482 \mathrm{~cm}^{-1}$, $\varepsilon \max =32.3 \mathrm{M}^{-1} \mathrm{~cm}^{-1}$ ) can be assigned also to band-to-band transitions from highest energetic level in the conduction band. It can be attributed to the excitation of free electron-hole pairs between $\mathrm{O}(2 \mathrm{~s}$ or $2 \mathrm{p})$ and $\mathrm{Cd}(5 \mathrm{~s})$ within $\left[\mathrm{CdCl}_{5}\left(\mathrm{H}_{2} \mathrm{O}\right)\right]^{-}$octahedron [42]. In addition, the band gap of hybrid compound determinates by using the Tauc method [43], and using the Kubelka-Munk function from the reflectance $\left.R\left[F(R)=(1-R)^{2} / 2 R\right)\right]$ is 2.42 ev (Fig.8). This value indicates that the title compound is a semiconductor with wide band gap [44].

Comparatively, fluorescent properties of the synthesized material were determined at room temperature. Fig. 9-b shows the emission spectrum, studied at the excitation wavelength of $280 \mathrm{~nm}$. The fluorescence spectrum exhibits three peaks in increasing order of intensity respectively at 348, 402 and $435 \mathrm{~nm}$. The two peaks at 402 and $435 \mathrm{~nm}$ agree well with recently reported emission peaks at around $423 \mathrm{~nm}$ on $\mathrm{CdCl}_{4}$ based materials [38]. Except that the degeneration on two peaks can be explained by the coexistence of the two $\left[\mathrm{CdCl}_{6}\right]^{2-}$ and $\left[\mathrm{CdCl}_{5}\left(\mathrm{H}_{2} \mathrm{O}\right)\right]^{-}$octahedrons. The third emission peak at $435 \mathrm{~nm}$ is under the estimated gap energy and then can be assigned to luminescence arising from excitonic states formed within the inorganic framework (bound electron-hole pairs). The emergence of excitonic emission with large stokes shift of some hundreds of $\mathrm{meV}$ (140 meV in this study) in several hybrid materials has been largely improved in recent decades. Moreover, the excitation spectrum 
which represents the variation of the intensity of the emission band at $400 \mathrm{~nm}$ as a function of excitation wave lengths is reported in Fig .9-a. It exhibits one band with maximum at $281 \mathrm{~nm}$.

The decay profile for compound recorded at $293 \mathrm{~K}$ is depicted in Fig. 10. The curve can be fitted well with single-exponential function $\mathrm{I}=\mathrm{I}_{0} \exp (-\mathrm{t} / \tau)$, where $\mathrm{I}_{0}$ and $\mathrm{I}$ are intensities at zero time and time $\mathrm{t}$, and $\tau$ is the lifetime, the latter is equal to $0.47 \mathrm{~ms}$.

\subsection{In vitro antioxidant activity of $\left[\mathrm{Cd}_{4} \mathrm{Cl}_{12}(\mathrm{H} 2 \mathrm{O})_{2}\right] \mathrm{n}\left(\mathrm{C}_{10} \mathrm{~N}_{4} \mathrm{H}_{28}\right) n$}

Oxidative stress is usually defined as a disturbance of the balance between oxidants and antioxidants in favor of the oxidants [45]. Indeed maintenance of a physiological level of oxidant, known as oxidative eustress, is essential for many cellular functions [46]. However excessive oxidant causes damage to biomolecules such as (ADN, lipids, and proteins [47] leading to many health diseases including cardiovascular diseases (CVD), neurological diseases and cancer [48].

Antioxidants have two main effects: improving stability of foods and improving human health. Actually, many researchers are interested by searching for new natural or synthetic antioxidant with improved activity. In this context we tried to evaluate the antioxidant activity of our new synthetized compound $\left[\mathrm{Cd}_{4} \mathrm{Cl}_{12}\left(\mathrm{H}_{2} \mathrm{O}\right)_{2}\right] \mathrm{n}\left(\mathrm{C}_{10} \mathrm{~N}_{4} \mathrm{H}_{28}\right)$ n. Two methods were used the DPPH radical scavenging and the ABTS radical scavenging.

DPPH test showed that $\left[\mathrm{Cd}_{4} \mathrm{Cl}_{12}\left(\mathrm{H}_{2} \mathrm{O}\right)_{2}\right] \mathrm{n}\left(\mathrm{C}_{10} \mathrm{~N}_{4} \mathrm{H}_{28}\right) \mathrm{n}$ have a low scavenging activity $\left(\mathrm{IC}_{50}=15.2 \pm 0.03 \mathrm{mg} / \mathrm{ml}\right)$ compared with the positive reference ascorbic acid $\left(\mathrm{IC}_{50}=0.14 \pm\right.$ $0.007 \mathrm{mg} / \mathrm{ml}$ ) (Table 4). This finding was confirmed with the result obtained in the ABTS test. $\left[\mathrm{Cd}_{4} \mathrm{Cl}_{12}\left(\mathrm{H}_{2} \mathrm{O}\right)_{2}\right] \mathrm{n}\left(\mathrm{C}_{10} \mathrm{~N}_{4} \mathrm{H}_{28}\right) \mathrm{n}$ showed low scavenging activity $\left(\mathrm{IC}_{50}=36.3 \pm 0.004\right.$ $\mathrm{mg} / \mathrm{ml}$ ) compared with the positive reference ascorbic acid (IC50 $=0.532 \pm 0.006 \mathrm{mg} / \mathrm{ml}$ ) (Fig.11).

\subsection{Determination of antibacterial activity by disc diffusion method}

The obtained results by the disc diffusion method, showed that $\left[\mathrm{Cd}_{4} \mathrm{Cl}_{12}\left(\mathrm{H}_{2} \mathrm{O}\right)_{2}\right]_{\mathrm{n}}$ $\left(\mathrm{C}_{10} \mathrm{~N}_{4} \mathrm{H}_{28}\right)_{\mathrm{n}}$ inhibition potential depended on bacteria. Indeed, the most important inhibition zone was recorded in Escherichia coli JW $1772(24.5 \pm 0.5 \mathrm{~mm})$, where $\left[\mathrm{Cd}_{4} \mathrm{Cl}_{12}\left(\mathrm{H}_{2} \mathrm{O}\right)_{2}\right]_{\mathrm{n}}$ $\left(\mathrm{C}_{10} \mathrm{~N}_{4} \mathrm{H}_{28}\right)_{\mathrm{n}}$ was more efficient than the reference antibiotic Streptomycin.

Nevertheless, for the rest of the tested bacteria, Streptomycin was more efficient than our new synthesized compound. Eventually, Pseudomonas aeruginosa SH 38, Enterococcus faecalis 
ATCC 29212 had the greatest resistance toward $\left[\mathrm{Cd}_{4} \mathrm{Cl}_{12}\left(\mathrm{H}_{2} \mathrm{O}\right)_{2}\right]_{\mathrm{n}}\left(\mathrm{C}_{10} \mathrm{~N}_{4} \mathrm{H}_{28}\right)_{\mathrm{n}}$ methanolic solution (inhibition zone $\approx 6 \mathrm{~mm}$ ) followed by Staphylococcus aureus NCTC 6571 (inhibition zone $=7 \pm 0.5 \mathrm{~mm}$ ) and Salmonella typhimurium ATCC 14028 (inhibition zone $=15 \pm 0.3$ ).

Results, issued from the in-vitro antibacterial activity, revealed that the sensitivity of the tested bacteria toward $\left[\mathrm{Cd}_{4} \mathrm{Cl}_{12}\left(\mathrm{H}_{2} \mathrm{O}\right)_{2}\right]_{\mathrm{n}}\left(\mathrm{C}_{10} \mathrm{~N}_{4} \mathrm{H}_{28}\right)_{\mathrm{n}}$ wasn't related to the structure of the bacterial membrane (Table 5, Fig.12).

\subsection{Thermal Behavior}

The thermal analysis (TG/DTA) results are reported in S.2. It was carried out under Ar atmosphere with heating rate of $5^{\circ} \mathrm{C} \cdot \mathrm{min}^{-1}$ ) in the range of $100-700 \mathrm{~K}$. The DTA curve shows that this compound undertakes two endothermic phenomena:

The first at $283 \mathrm{C}^{\circ}$ corresponds to evaporation of $\mathrm{Cd}(\mathrm{II})$ coordinated water molecule confirmed with a weight loss in the curve of TG (experimental weight loss: $2.7 \%$ and calculated weight loss: $3.22 \%)$.

The second at $341 \mathrm{C}^{\circ}$, corresponds to the degradation of the organic entity and the release of chloride acid molecule arising from an intermolecular elimination reaction, with an important weight loss observed in TG curve in the temperature range of 100-700 $\mathrm{C}^{\circ}$. A black deposit of carbon was obtained at the end of the experience.

\section{Conclusion}

In this paper we have reported the synthesis, characterization and crystal structure of a new single crystal of an organic-inorganic hybrid compound $\left[\mathrm{Cd}_{4} \mathrm{Cl}_{12}\left(\mathrm{H}_{2} \mathrm{O}\right)_{2}\right] \mathrm{n}\left(\mathrm{C}_{10} \mathrm{~N}_{4} \mathrm{H}_{28}\right) \mathrm{n}$. The hybrid compound $\left[\mathrm{Cd}_{4} \mathrm{Cl}_{12}\left(\mathrm{H}_{2} \mathrm{O}\right)_{2}\right]_{\mathrm{n}}\left(\mathrm{C}_{10} \mathrm{~N}_{4} \mathrm{H}_{28}\right)_{\mathrm{n}}$ crystallize in a monoclinic system with a P2 1 /n space group. The cohesion of the molecules in the crystal was made by the hydrogen bonds of the $\mathrm{N}-\mathrm{H} . . . \mathrm{Cl}, \mathrm{C}-\mathrm{H} . . . \mathrm{Cl}$, and $\mathrm{O}-\mathrm{H} . . . \mathrm{Cl}$ between the inorganic covalent framework and the organic cations. Also the calculation of Hirshfeld surfaces has highlighted the different interactions that exist within the crystal. The IR absorption spectroscopy investigation of the compound has made it possible to identify the vibrational characteristic bands. The study by the UV-Visible solid state spectrophotometry technique made it possible to determine the characteristic absorption bands, thus having an idea of its semiconductor behavior. Finally the bioassay results showed that the structure exhibits significant antibacterial activity and the 
thermal analysis (TG/DTA) results have an idea about the path of decomposition of the material.

\section{Supplementary data}

Crystallographic data for the structural analysis have been deposited at the Cambridge Crystallographic Data Centre, $N^{\circ}$ de Cambridge: CCDC 1576947

\section{References}

[1] D.B.Mitzi, A layered solution crystal growth technique and the crystal structure of $\left(\mathrm{C}_{6} \mathrm{H}_{5} \mathrm{C}_{2} \mathrm{H}_{4} \mathrm{NH}_{3}\right)_{2} \mathrm{PbCl}_{4}$, Solid State Chem. 145 (1999) 697-704.

[2] G.C. Papavassiliou, Three- and low-dimensional inorganic semiconductors, Solid State Chem. 25 (1997) 125.

[3] M.Era, S.Morimoto, T.Tsutsui, S.Saito, Organic- inorganic heterostructure electroluminescent device using a layered perovskite semiconductor $\left(\mathrm{C}_{6} \mathrm{H}_{5} \mathrm{C}_{2} \mathrm{H}_{4} \mathrm{NH}_{3}\right)_{2} \mathrm{PbI}_{4}$, Appl. Phys. Lett. 65 (1994) 676.

[4] A.Ben Ahmed, H. Feki, Y.Abid, Synthesis, crystal structure, vibrational spectroscopy, optical properties and theoretical studies of a new organic-inorganic hybrid material $\left[\left(\left(\mathrm{CH}_{3}\right)_{2} \mathrm{NH}^{2+]} 6[\mathrm{BiBr}]^{3-}\right]_{2}\right.$, Spectrochimica Acta Part: Molecular and biomolecular spectroscopy.133 (2014) 357-364.

[5] K. Karoui, A.B. Rhaiem, K. Guidara, Dielectric properties and relaxation behavior of [TMA] $2 \mathrm{Zn}_{0.5} \mathrm{Cu}_{0.5} \mathrm{Cl}_{4}$ compound, Phys. B. 407 (2012) 489-49

[6] K. Sakai, M. Takemura, Y. Kawabe, Lead chloride-based layered perovskite incorporated with an excited state intramolecular proton transfer dye, J. Lumin.130 (2010) 2505-2507.

[7] M. Wojtas, R. Jakubas, Z. Ciunik, W. Medycki, J. Solid State Chem. 177 (2004) 1775.

[8] G. Bator, Th Zeegers-Huyskens, R. Jakubas, J. Zaleski, J. Mol. Struct. 570 (2001) 61.

[9] B. Kulicka, T. Lis, V. Kinzhybalo, R. Jakubas, A. Piecha, Polyhendrom 29 (2010) 2014.

[10] D. W. Smith, Chlorocuprates (II), Coor. Chem. Rev. 21 (1976) 93-158.

[11] J. Tao, X. Yin, L. F. Jiang, R. B. Huang, L. S. Zheng, Syntheses and crystal structures of two novel zinc(II) coordination polymers, Eur. J. Inorg. Chem. 14 (2003) 2678 -2682.

[12] Kaur, K., Jain, M., Reddy, R.P. \& Jain, R, Quinolines and structurally related heterocycles as antimalarials, Eur. J. Med. Chem., 45 (2010) 3245-3264. 
[13] Eswaran, S., Adhikari, A. V., Chowdhury, I.H., Pal, N.K. \& Thomas, K. D, Emerging Research on Bioinspired Materials Engineering, Eur. J. Med. Chem. 45 (2010) 3374-3383.

[14] Chou, L. C., Tsai, M. T., Hsu, M. H., Wang, S. H., Way, T.D., Huang, C. H., Lin, H. Y., Qian, K., Dong, Y., Lee, K. H., Huang, L. J. \& Kuo, S. C, Design, synthesis, and preclinical evaluation of new 5,6- (or 6,7-) disubstituted-2-(fluorophenyl)quinolin-4-one derivatives as potent antitumor agents, J. Med. Chem. 53 (2010), 8047-8058.

[15] Chen, Y. L., Hung, H. M., Lu, C. M., Li, K. C. \& Tzeng, C. C. Synthesis and anticancer evaluation of certain indolo[2,3-b]quinoline derivatives, Bioorg. Med. Chem. 12 (2004), 6539-6546.

[16] Shingalapur, R. V., Hosamani, K. M. \& Keri, R. S. Synthesis and evaluation of in vitro anti-microbial and anti-tubercular activity of 2-styryl benzimidazoles, Eur. J. Med. Chem, 44 (2009) 4244-4248.

[17] Shchekotikhin, A. E., Shtil, A. A., Luzikov, Y. N., Bobrysheva, T. V., Buyanov, V. N. \& Preobrazhenskaya, M. N. 3-Aminomethyl derivatives of 4,11-dihydroxynaphtho[2,3f]indole-5,10-dione for circumvention of anticancer drug resistance, Bioorg. Med. Chem. 13 (2005) 2285-2291.

[18] Faist, J., Seebacher, W., Saf, R., Brun, R., Kaiser, M. \& Weis, R. New Nmethylpiperazinyl derivatives of bicyclic antiprotozoal compounds. Eur. J. Med. Chem. 47 (2012) 510-519.

[19] Kulig, K., Sapa, J., Maciag, D., Filipek, B. \& Malawska, B. 1- (3- (4- Arylpiperazin- 1- yl)- propyl)- Pyrrolidin- 2- one Derivatives as a1- Adrenoceptor Antagonists. Arch. Pharm. Chem. Life Sci. 340 (2007), 466-475.

[20] G. M. Sheldrick, Acta Cryst. A71 (2015) 3-8.

[21] Sheldrick G.M., Acta Cryst. C71 (2015) 3-8.

[22] K. Brandenburg 1998 DIAMOND version 2.0.

[23] Brace, A., Tommasi, N. D., Bari, L. D., Pizza, C., Politi, M., Morelli, I.. Antioxidant principles from Bauhinia terapotensis. Journal of Natural Products. 64 (2001), 892-895.

[24] Re, R., Pellegrini, N., Proteggente, A., Pannala, A., Yong, M., Rice-Evans, C. Antioxidant activity applying an improved ABTS radical cation decolorization assay. Free Radical Biology \& Medicine. 26 (1999), 1231-1237.

[25] M. El Glaoui, M. Zeller, E. Jeanneau, C. Ben Nasr, Acta Cryst. Bis(1-benzylpiperazine1,4-diium) hexachloridocadmate(II) dehydrate, E66 (2010) m895.

[26] C. Janiak, T.G. Scharmann, Polyhedron, Supramolecular C $\square \mathrm{H} \cdots \mathrm{O}, \mathrm{C} \square \mathrm{H} \cdots \mathrm{N}$ and $\mathrm{C} \square \mathrm{H} \cdots \mathrm{Cl}$ interactions in metal compounds with multi-topic poly(pyrazolyl)borate ligands, 22 (2003) 1123. 
[27] S.F. Haddad, M.A. AlDamen, R.D. Willett, Inorg. Chim. Acta. The role of non-classical supramolecular interactions in the structures of 2-amino-4,6-dimethylpyridinium tetrahalocuprate (II) salts.359 (2006) 424.

[28] B. Jasiewicz, W. Boczon', D. Muth, B. War_zajtis, U. Rychlewska, B.Andrzejewski,T. Tolin' ski, J. Mol. Struct. Crystal structure, spectroscopy and magnetism of selected (-)sparteine and $\alpha$-isosparteine tetrahalocuprate salts, 794 (2006) 311.

[29] D. Braga, S.M. Draper, E. Champeil, F. Grepioni, J. Organomet. Chem.Crystal Structure, Spectroscopic and Thermal Investigations of a New 4-Ammonio-2,2,6,6tetramethylpiperidinium Tetrachlorozincate (II), 57 (1999) 373

[30] S. Soudani , V. Ferretti , C. Jelsch, F. Lefebvre , C. Ben Nasr J. Solid State Chem. Synthesis, structural characterization, Hirshfeld surface analysis and spectroscopic studies of cadmium (II) chloride complex with 4-hydroxy-1-methylpiperidine237 (2016)7-13

[31] H-L. Jiang, J-G.Mao, Inorg. Chem. Syntheses, crustal structures and optical properties of the first strontium (IV) and tellurium (IV) oxychlorides. 45 (2006) 717-721.

[32] S. Vetrivel, E. Vinoth, R. U. Mullai, R. Aruljothia and M. NizamMohideen, Acta Cryst. (2016). Crystal structure of 1,4-bis(3-ammoniopropyl)piperazine-1,4-diium bis[dichromate (VI)] E72, 616-619.

[33] S.K. Wolff, D.J. Grimwood, J.J. McKinnon, M.J. Turner, D. Jayatilaka, M.A. Spackman, Crystal Explorer (Version 3.1), University of Western Australia, 2012.

[34] J. McKinnon, D. Jayatilaka, M.A. Spackman, J. Chem. Commun. Towards quantitative analysis of intermolecular interactions with Hirshfeld surfaces. 37.(2007)., 3814.

[35] MCKINNON J. J., SPACKMAN M. A., MITCHELL A. S- Acta Crystallographica Section B, Novel tools for visualizing and exploring intermolecular interactions in molecular crystals B60, (2004), 627-66

[36] C. F. Matta, J. Hernandez-Trujillo, T. H. Tang, R. F. W. Bader, Hydrogen-Hydrogen Bonding: A Stabilizing Interaction in Molecules and Crystals, Chem. Eur. J. 9 (2003)

1940-195

[37] B. Guillot, E. Enrique, L. Huder, C. Jelsch, Acta Cryst. MoProViewer: a tool to study proteins from a charge density science perspective .A70, (2014),C279.

[38] A.C. Dhieb, A.Valkonen, M.Rzaigui,W. Smirani, Journal of Molecular Structure, Synthesis, crystal structure, physico-chemical characterization and dielectric properties of a new hybrid material, 1-Ethylpiperazine-1, 4-diium tetrachlorocadmate 1102, (2015) 50-56.

[39] I. Lahbib, M.Rzaigui, W.Sta, Journal of Molecular Structure, Synthesis crystal structure spectroscopic thermal and dielectric properties of a novel semi-organic pentachlorantimonate (III), 1120 (2016) 250e258. 
[40] S. Soudani , J.-X.Mi, F.Lefebvre, C. Jelsch, C.Ben Nasr, Synthesis and physic-chemical studies of a novel layred structure with a heptanuclear Cd complex, Journal of Molecular Structure 1084 (2015) 46-54

[41] Y. Baklouti, N. Chaari, H. Feki, N.C. Boudjada, F. Zouari, Crystal structure, vibrational studies, optical properties and DFT calculations of 2-amino-5-diethyl-aminopentanium tetrachlorocadmate (II), Spectrochimica Acta Part A: Molecular and Biomolecular Spectroscopy 136 (2015) 397-404.

[42] Z.Dega-Szafran, A.Katrusiak, M. Szafran, Journal of Molecular Structure, Experimental and theorical studies of 4-hydroxy-1methylpiperidium perchlorate 889,(2008) 344-351.

[43] Sies, H. 1997. Physiological symposium: Impaired endothelial and smooth muscle cell function in oxidative stress. In oxidative stress. Oxidants and antioxidants. Experimental Physiology. 82. 291-295

[44] Valko, M., Leibfritz, D., Moncol, J., Cronin, M.T.D., Mazur, M., Telser, J. 2007. Free radicals and antioxidants in normal physiological functions and human disease. International Journal Biochemistry and Cell Biology. 39: 44-84.

[45] Sies, H. 1997. Physiological symposium: Impaired endothelial and smooth muscle cell function in oxidative stress. In oxidative stress. Oxidants and antioxidants. Experimental Physiology. 82. 291-295

[46] Bouayed, J., Bohn, T. 2010. Exogenous antioxidants - Double-edged swords in cellular redox state: Health beneficial effects at physiologic doses versus deleterious effects at high doses. Oxidative Medicine and Cellular Longevity. 3(4), 228-237.

[47] Sies, H., Berndt, C., and Jones, D.P. 2017. Oxidative Stress. Annual Review of Biochemistry. 20 (86): $715-748$

[48] Schoneich, C., Hewarathna, A., Pal, R., Jiang, L., Michaelis, E. 2017. P 236 - oxidative stress markers of Alzheimer's disease in peripheral cell mitochondria. Free Radical Biology and Medicine. 108 (1): S100. 


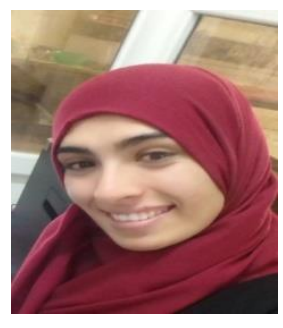

Aroussia Hachani is a PhD student at the Faculty of Science of Bizerte.

She was born in Bizerte, a city located north of Tunisia. She is preparing her doctoral thesis on organic-inorganic hybrid materials under the supervision of Kefi Riadh, lecturer at the Materials Chemistry Laboratory since 2017

\section{Figure captions}

Fig. 1

Coordination environment of the $\mathrm{Cd}(\mathrm{II})$ atom with atomic labels in

$\left[\mathrm{Cd}_{4} \mathrm{Cl}_{12}\left(\mathrm{H}_{2} \mathrm{O}\right)_{2}\right] \mathrm{n}\left(\mathrm{C}_{10} \mathrm{~N}_{4} \mathrm{H}_{28}\right)$ n.

Fig. 2

Projection along the b-axis of the crystal packing of the title compound. The dotted lines indicate hydrogen bonds.

Fig. 3

View along the [101] direction of an inorganic layer in the title compound.

Fig.4 
Hirshfeld surface analysis of $\left[\mathrm{Cd}_{4} \mathrm{Cl}_{12}\left(\mathrm{H}_{2} \mathrm{O}\right)_{2}\right] \mathrm{n}\left(\mathrm{C}_{10} \mathrm{~N}_{4} \mathrm{H}_{28}\right) \mathrm{n}$ : (a) $\mathrm{d}_{\text {norm }},(\mathbf{b}) \mathrm{d}_{\mathrm{e}},(\mathbf{c})$ curvedness, (d) $d_{i},(\mathbf{e})$ shape-index.

Fig. 5

Fingerprint plots of major contacts in $\left[\mathrm{Cd}_{4} \mathrm{Cl}_{12}\left(\mathrm{H}_{2} \mathrm{O}\right)_{2}\right] n\left(\mathrm{C}_{10} \mathrm{~N}_{4} \mathrm{H}_{28}\right) n$.

Fig. 6

The relative contributions to the Hirshfeld surface area for $\left[\mathrm{Cd}_{4} \mathrm{Cl}_{12}\left(\mathrm{H}_{2} \mathrm{O}\right)_{2}\right] \mathrm{n}\left(\mathrm{C}_{10} \mathrm{~N}_{4} \mathrm{H}_{28}\right) \mathrm{n}$

Fig. 7

Correlation graph between the experimental and calculated wavenumbers $\left(\mathrm{cm}^{-1}\right)$.

Fig.8

Optical absorption spectra measured at room temperature and the gap band.

Fig. 9

(a) Excitation and (b) emission spectra of $\left[\mathrm{Cd}_{4} \mathrm{Cl}_{12}\left(\mathrm{H}_{2} \mathrm{O}\right)_{2}\right] \mathrm{n}\left(\mathrm{C}_{10} \mathrm{~N}_{4} \mathrm{H}_{28}\right)$ n compound.

Fig.10

PL decay curves measured at $\lambda=280 \mathrm{~nm}$

Fig. 11

DPPH Radical scavenging activity. The data are reported as mean \pm standard deviation. B: Ascorbic Acid, A: tested compound.

\section{Fig.12}

ABTS radical scavenging activity. The data are reported as mean \pm standard deviation. B: tested compound., A: Ascorbic Acid 


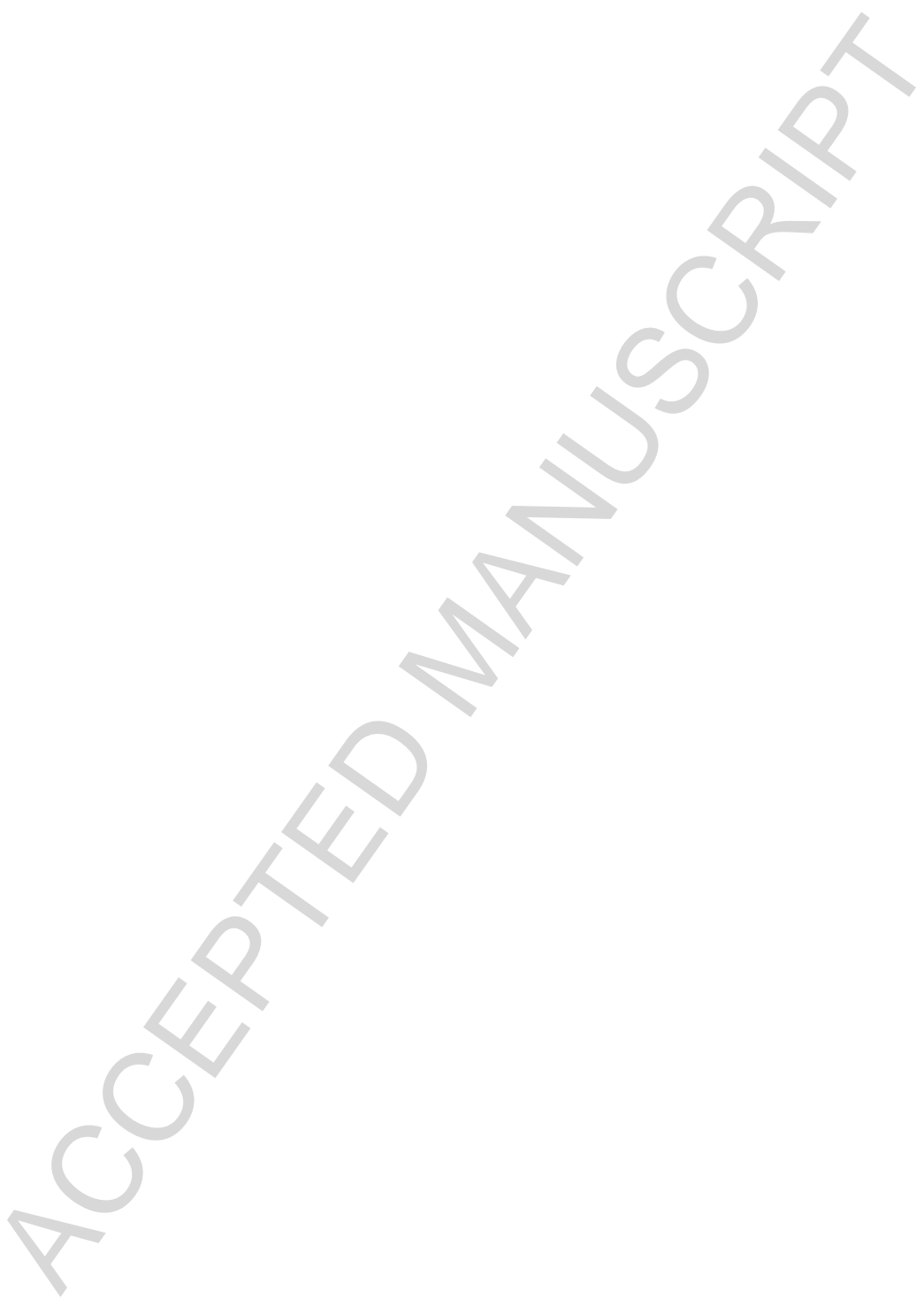




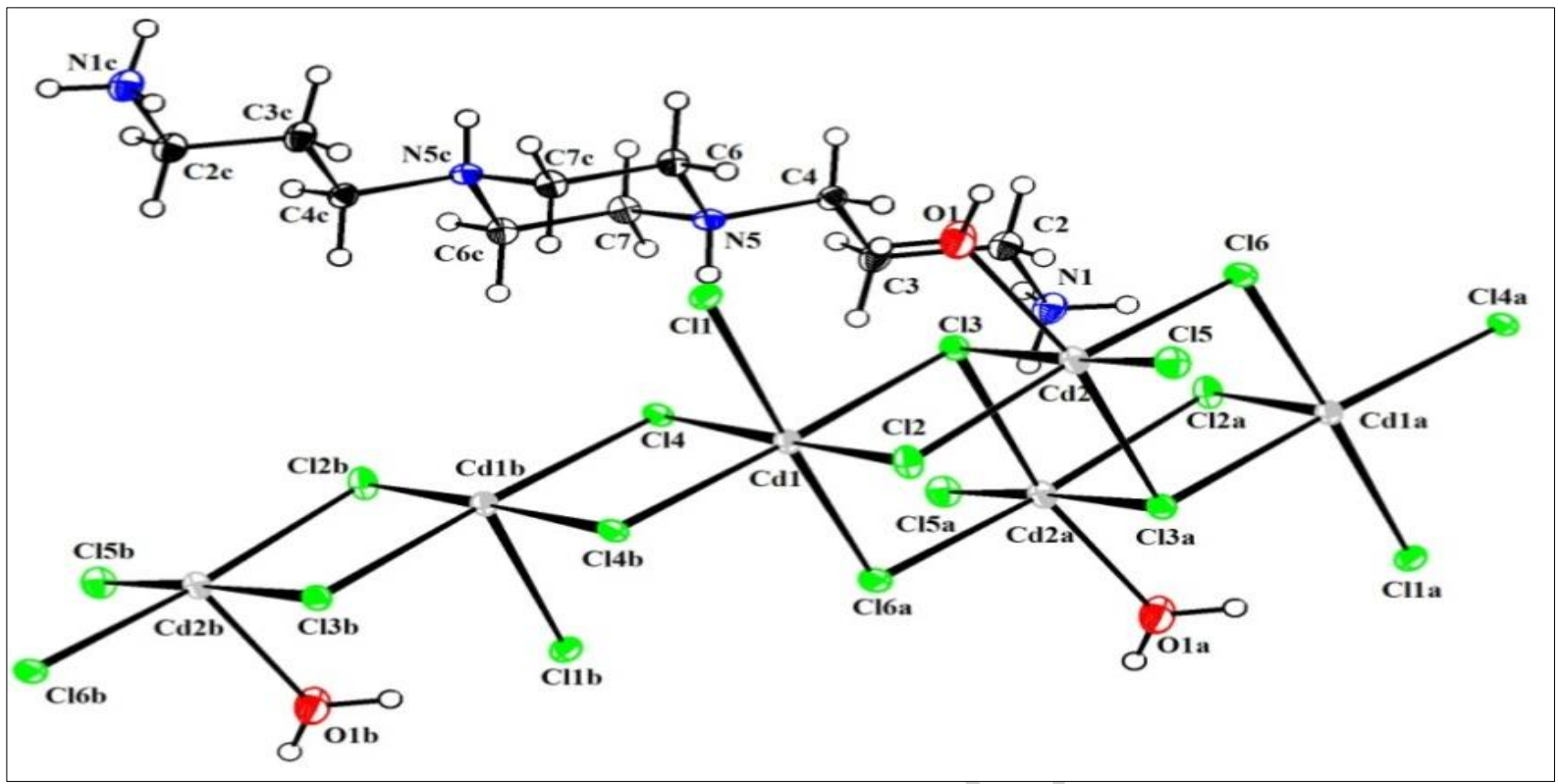

Fig.1

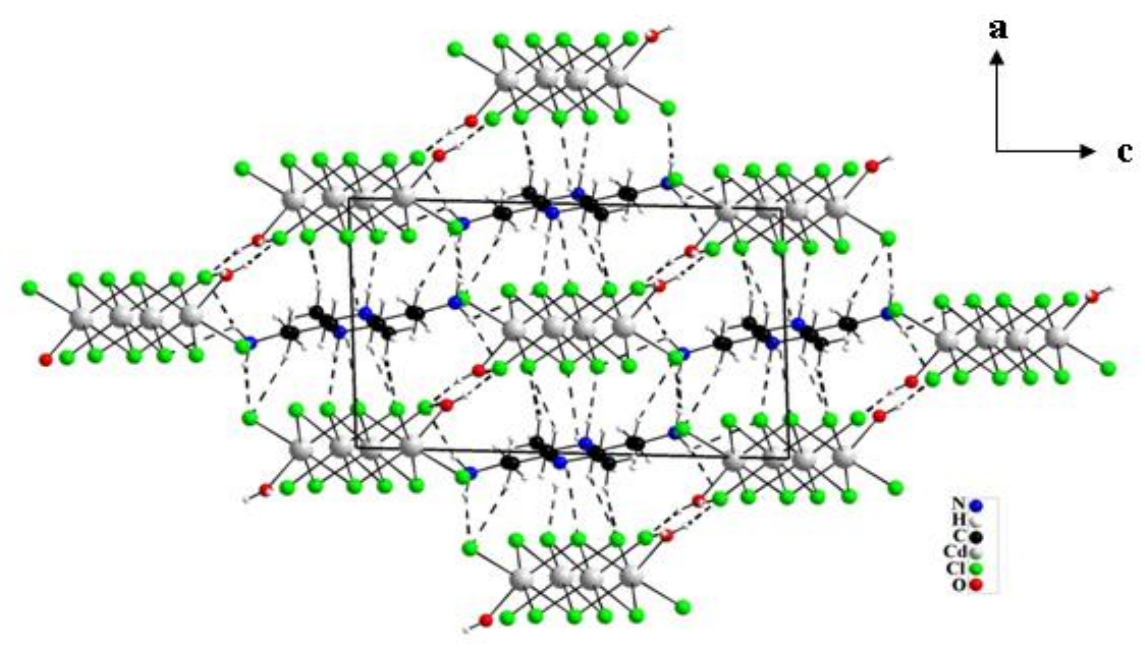

Fig.2 


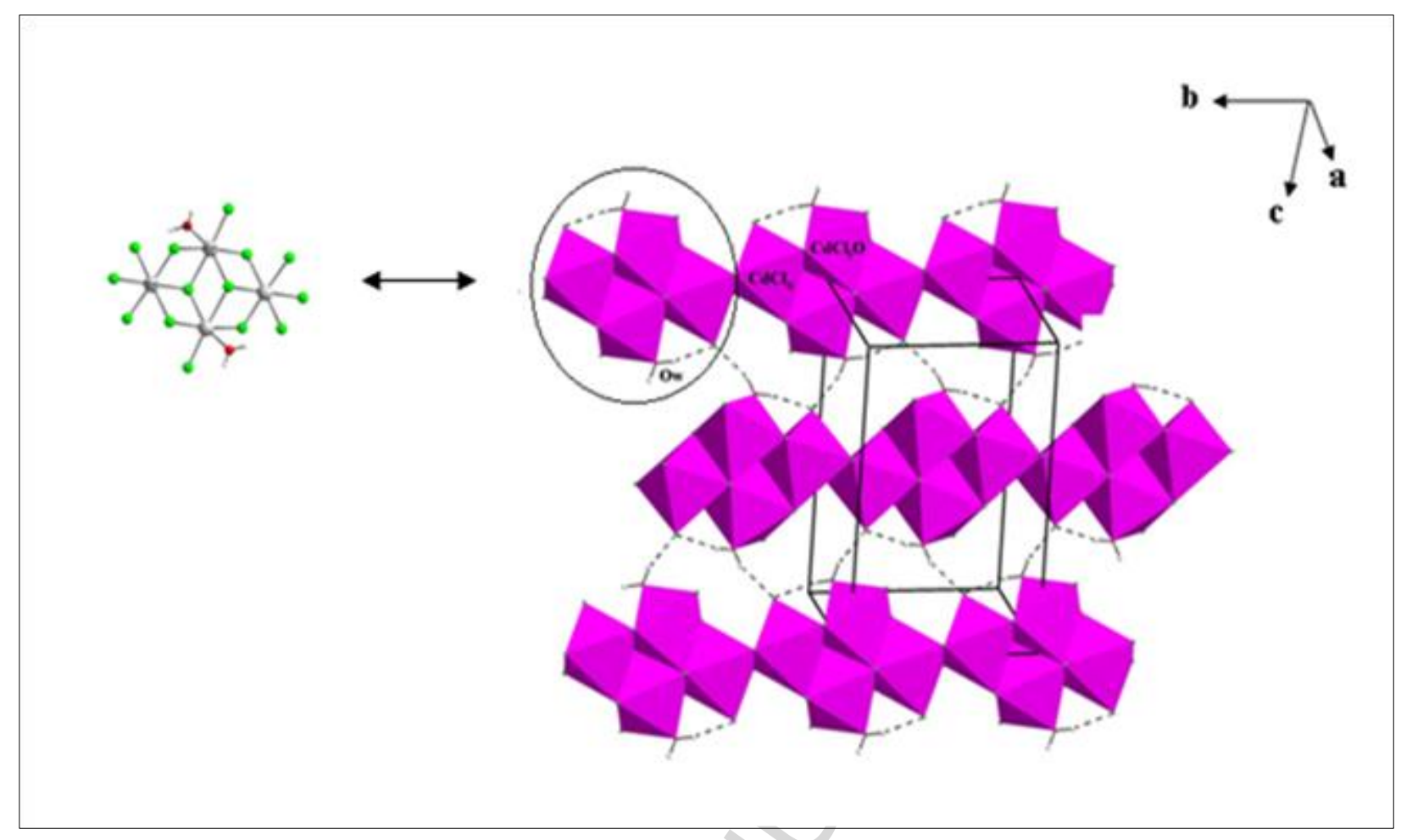

Fig.3

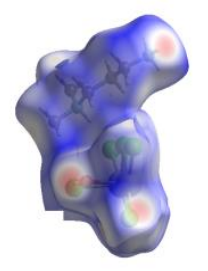

(a)

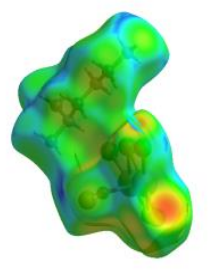

(b)

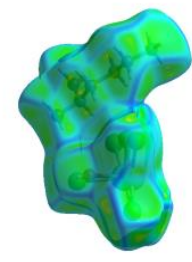

(c)

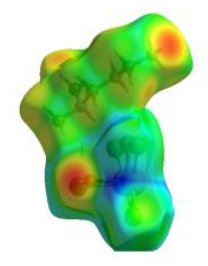

(d)

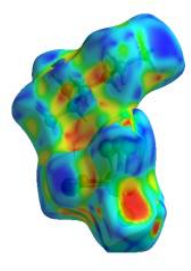

(e)

Fig.4 


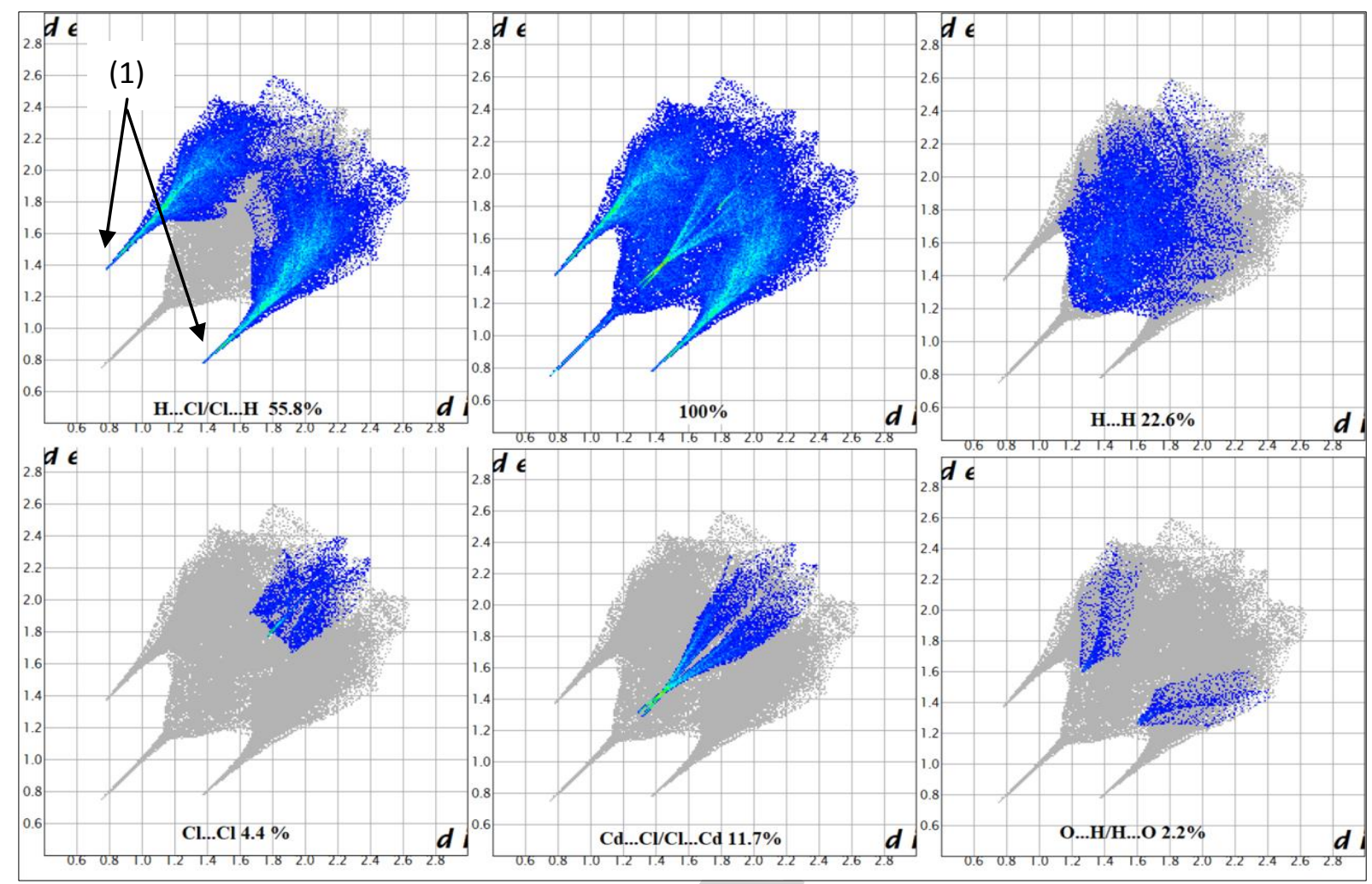

Fig.5

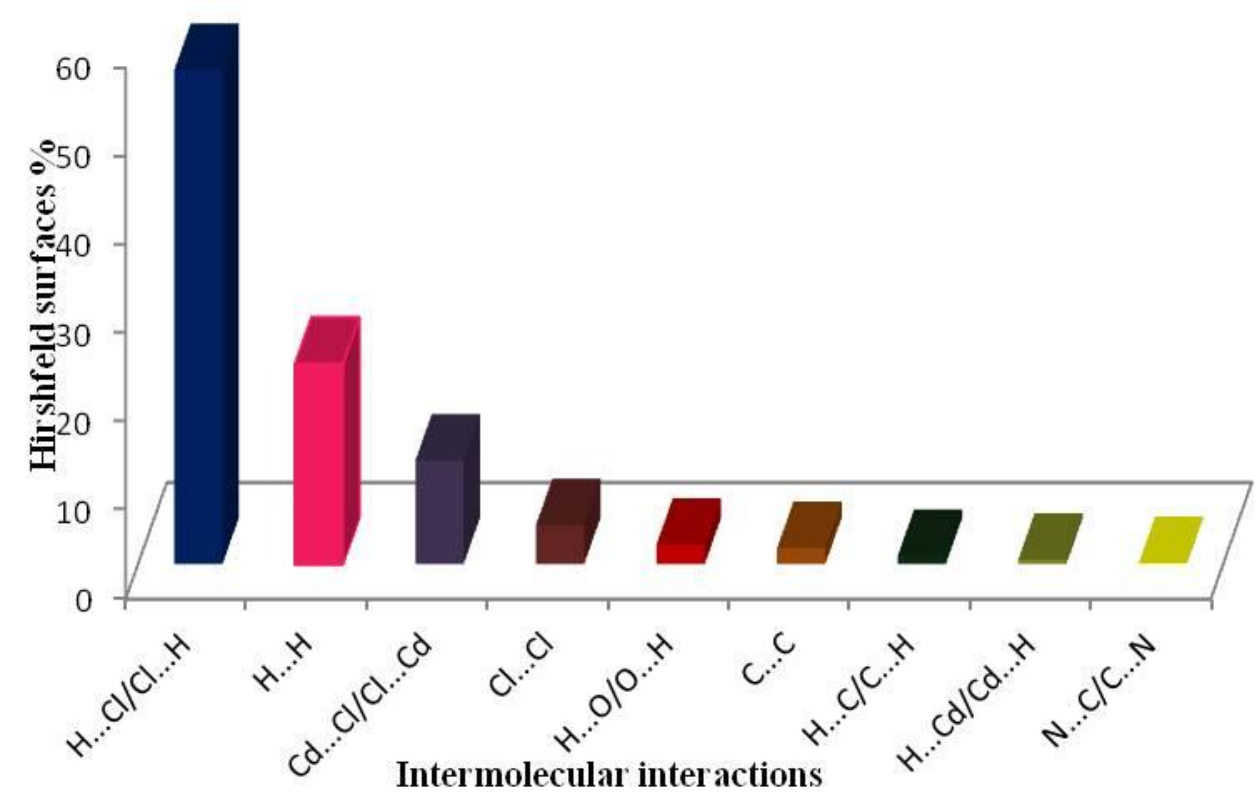

Fig.6 


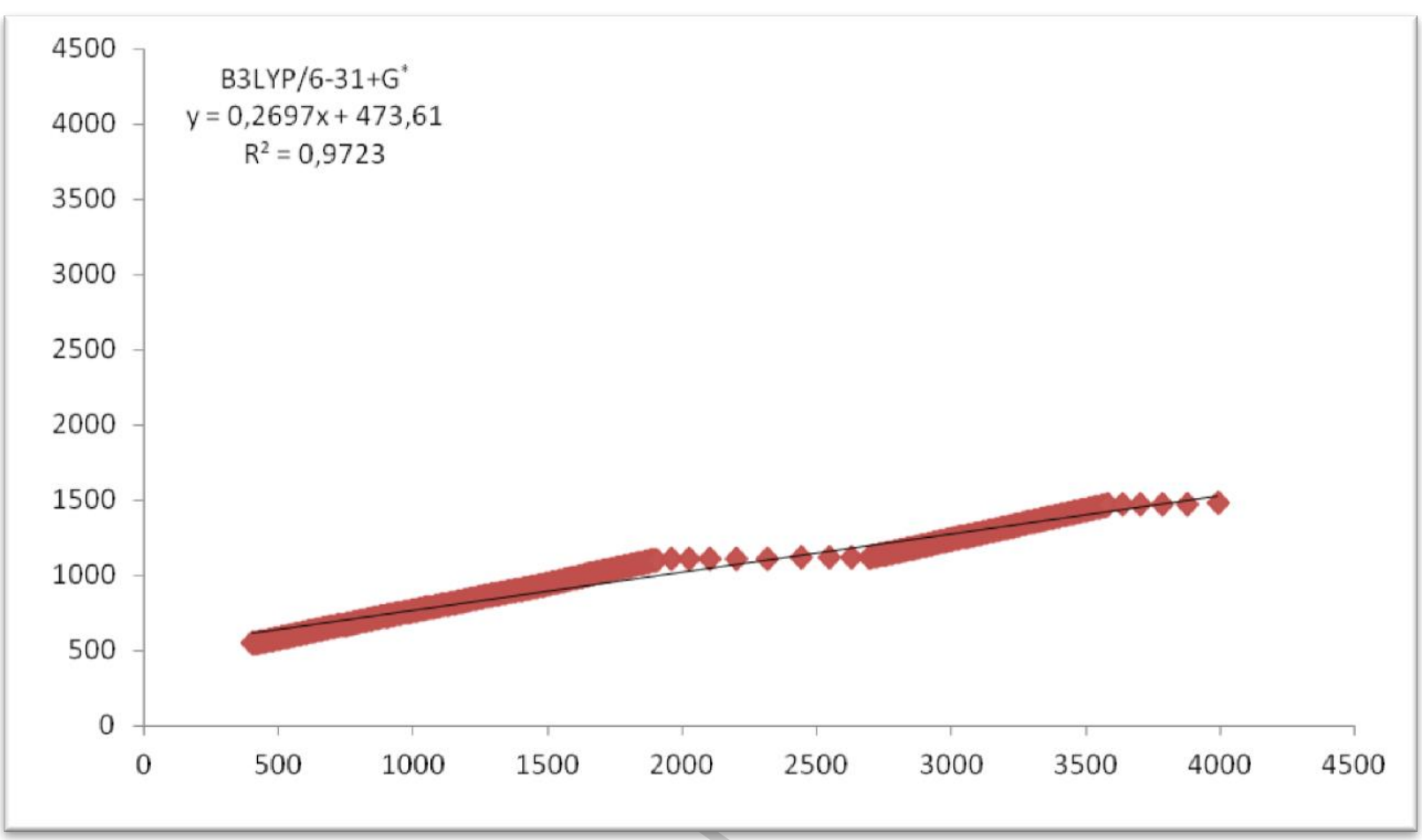

Fig.7

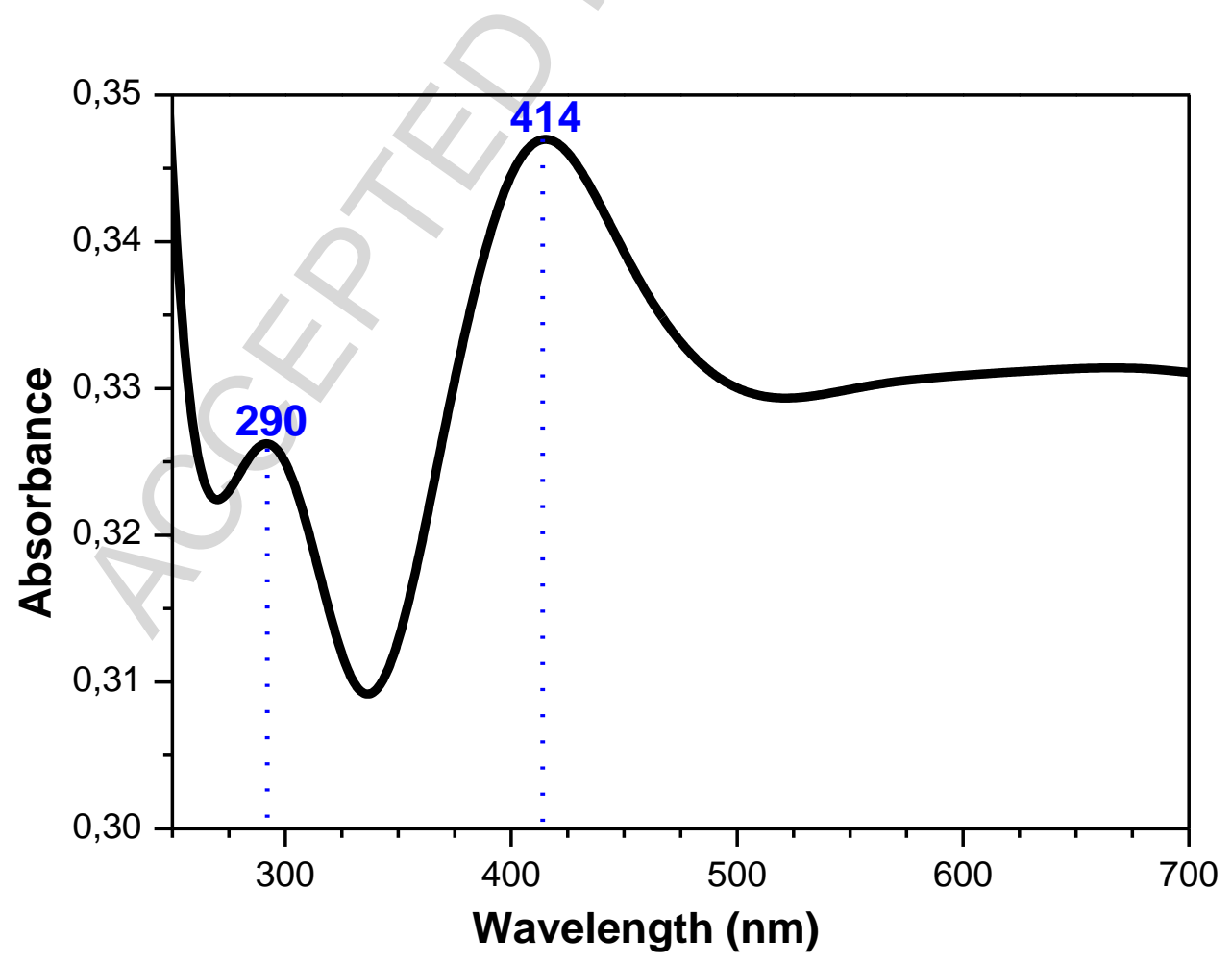

Fig.8 


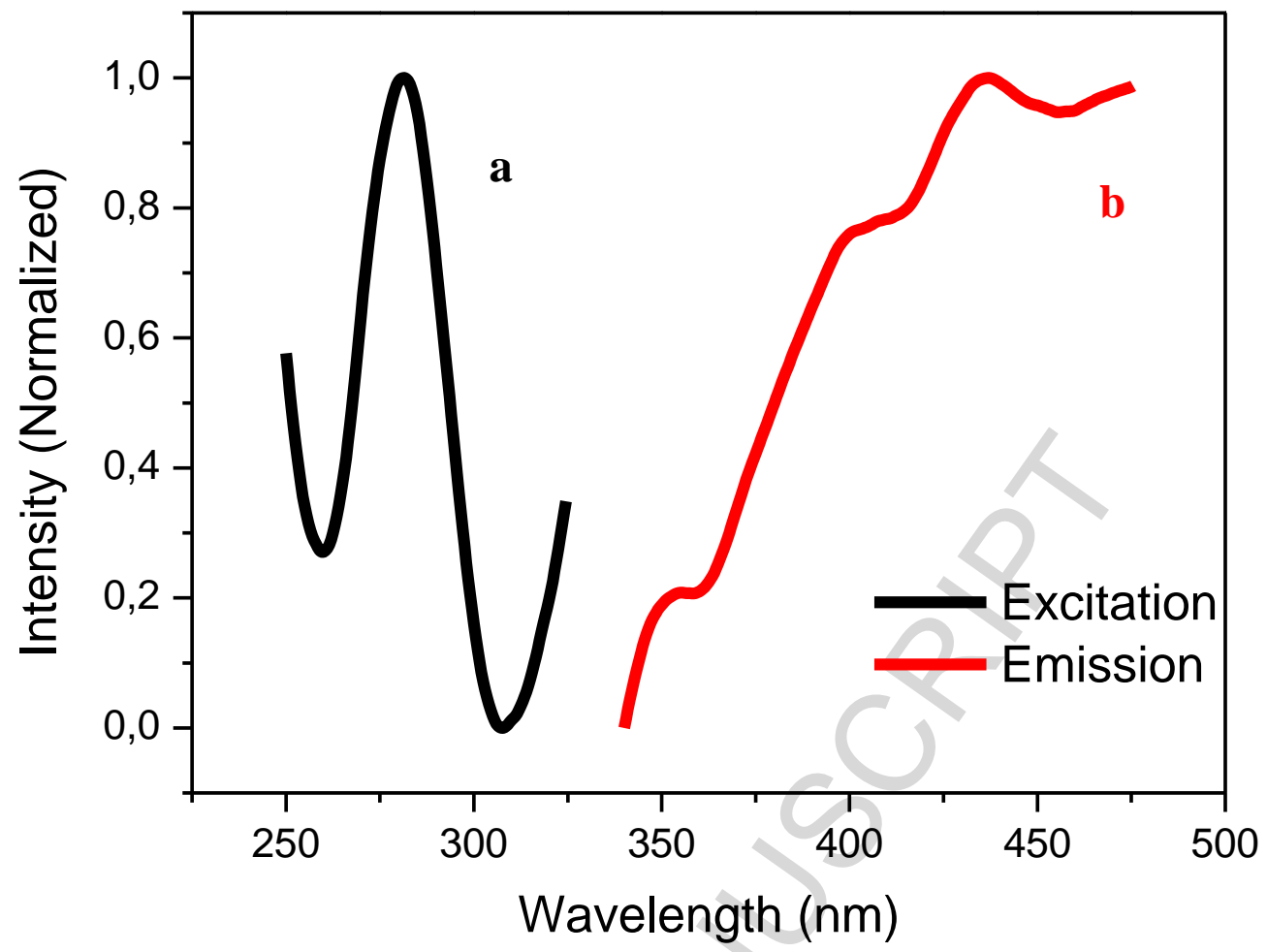

Fig.9

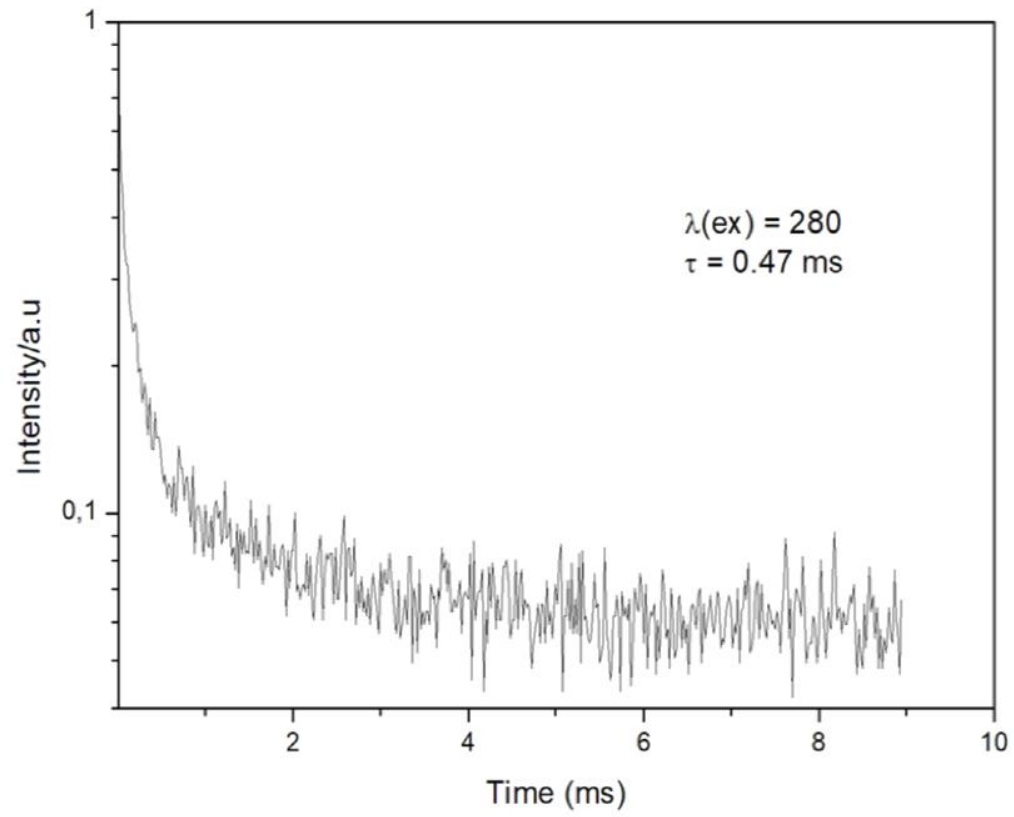

Fig.10 

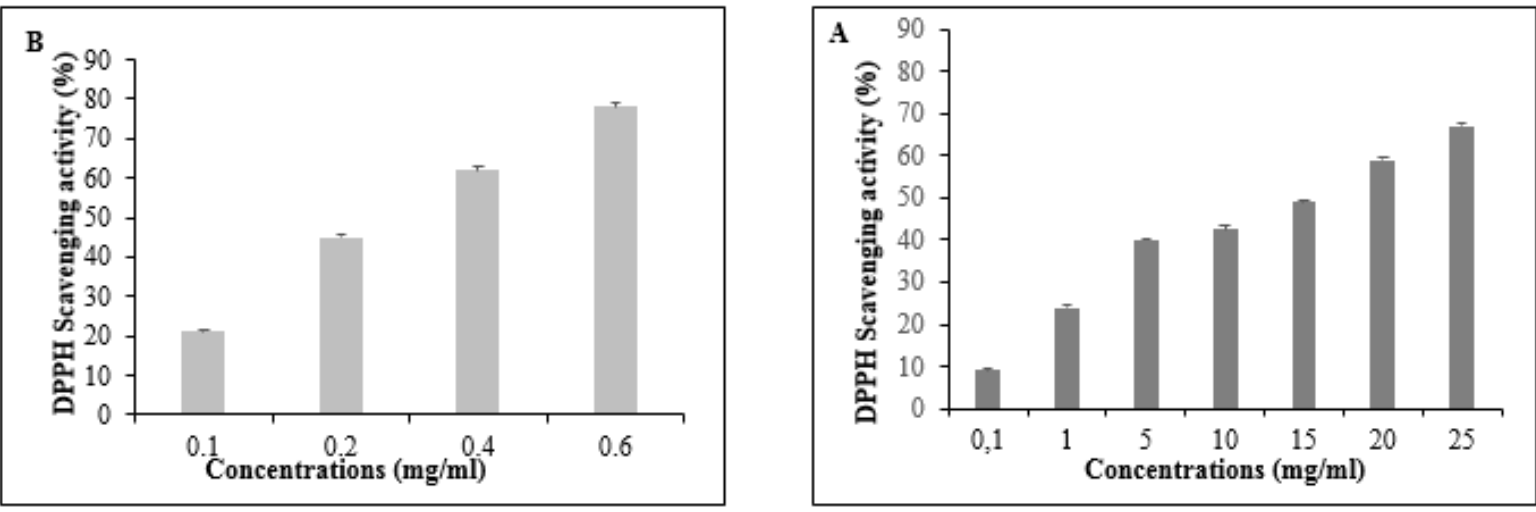

Fig.11
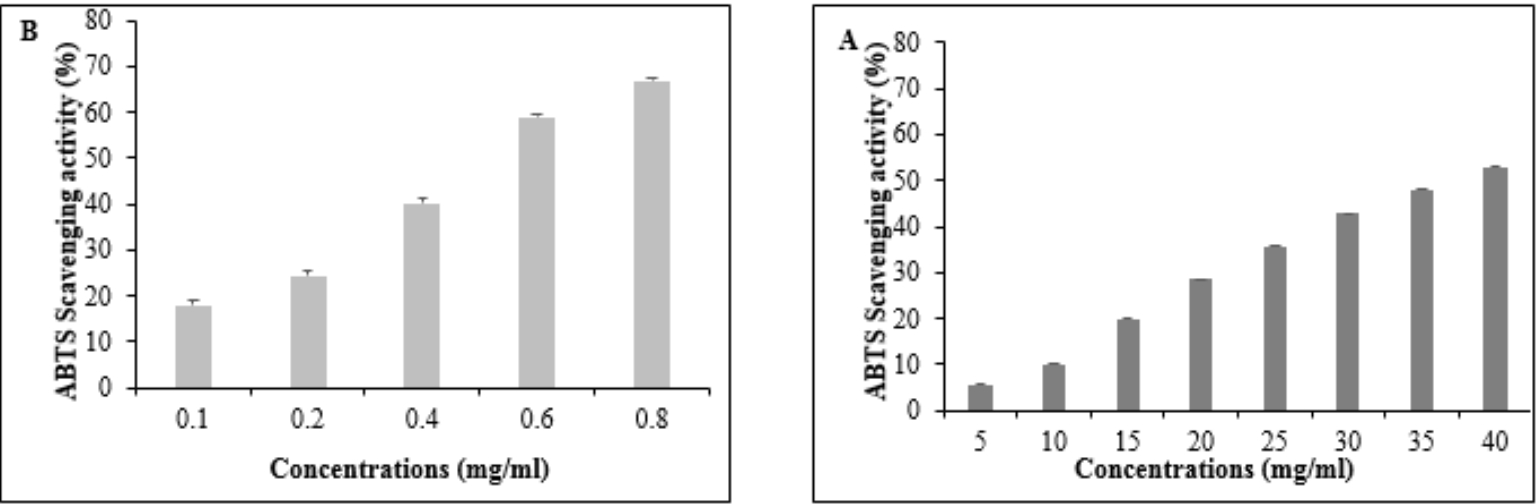

Fig.12 
Table 1. Experimental details of $\left[\mathrm{Cd}_{4} \mathrm{Cl}_{12}\left(\mathrm{H}_{2} \mathrm{O}\right)_{2}\right] \mathrm{n}\left(\mathrm{C}_{10} \mathrm{~N}_{4} \mathrm{H}_{28}\right) \mathrm{n}$

\section{Crystal data}

Chemical formula

$\mathrm{Cd}_{4} \mathrm{Cl}_{12} \mathrm{H}_{4} \mathrm{O}_{2} \cdot \mathrm{C}_{10} \mathrm{H}_{28} \mathrm{~N}_{4}$

$\mathrm{Mr}$

1115.39

Crystal system

Monoclinic

Space group

$P 2{ }_{1} / n$

Temperature $(\mathrm{K})$

150

$a, b, c(\AA)$

9.5808 (17), $9.8438(18), 16.050$ (3)

$\beta\left(^{\circ}\right)$

$93.142(6)$

$V\left(\AA^{3}\right)$

$1511.4(5)$

$Z$

2

Radiation type

Mo $K \alpha$

$\mu\left(\mathrm{mm}^{-1}\right)$

3.86

Crystal size (mm)

$0.58 \times 0.34 \times 0.22$

Data collection

Diffractometer

D8 VENTURE Bruker AXS

Absorption correction

Multi-scan

Tmin, Tmax

$0.199,0.428$

No. of measured, independent and observed [I

14806, 3453, 3312

$2 \sigma(I)]$ reflections

Rint

0.052

\section{Refinement}

$R\left[F^{2}>2 \sigma\left(F^{2}\right)\right], w R\left(F^{2}\right), S$

$0.028,0.071,1.19$

No. of reflections

3453

No. of parameters

164

$\Delta \rho \max , \Delta \rho \min \left(\mathrm{e} \AA^{-3}\right)$

$1.03,-1.24$ 
Table 2: Hydrogen-bond geometry $\left(\AA,^{\circ}\right)$.

\begin{tabular}{|c|c|c|c|c|}
\hline $\mathrm{D}-\mathrm{H} \ldots \mathrm{A}$ & $\mathrm{D}-\mathrm{H}$ & $\mathrm{H} \ldots \mathrm{A}$ & $\mathrm{D} \ldots \mathrm{A}$ & $\mathrm{D}-\mathrm{H} \ldots \mathrm{A}$ \\
\hline $\mathrm{N} 1-\mathrm{H} 1 \mathrm{~A} \ldots \mathrm{Cl} l_{5}^{a}$ & $0.92(2)$ & $2.40(3)$ & $3.290(3)$ & $164(3)$ \\
\hline $\mathrm{N} 1-\mathrm{H} 1 \mathrm{~B} \ldots \mathrm{Cl} l_{5}^{b}$ & $0.90(2)$ & $2.46(3)$ & $3.357(3)$ & $178(3)$ \\
\hline $\mathrm{N} 1-\mathrm{H} 1 \mathrm{C} \ldots \mathrm{Cl} l_{1}^{c}$ & $0.91(2)$ & $2.39(3)$ & $3.277(3)$ & $167(3)$ \\
\hline $\mathrm{N} 5-\mathrm{H} 5 \ldots \mathrm{Cl} l_{4}$ & $0.87(3)$ & $2.30(3)$ & $3.149(2)$ & $166(3)$ \\
\hline $\mathrm{O} 1-\mathrm{H} 11 \mathrm{~A} \ldots C l_{1}^{f}$ & $0.89(3)$ & $2.24(3)$ & $3.085(2)$ & $158(4)$ \\
\hline $\mathrm{O} 1-\mathrm{H} 11 \mathrm{~B} \ldots l_{1}$ & $0.91(3)$ & $2.23(3)$ & $3.125(3)$ & $166(4)$ \\
\hline $\mathrm{C} 3-\mathrm{H} 3 \mathrm{~B} \ldots l_{5}^{a}$ & 0.97 & 2.81 & $3.637(3)$ & 143.8 \\
\hline $\mathrm{C} 4-\mathrm{H} 4 \mathrm{~A} \ldots \mathrm{Cl} l_{3}$ & 0.97 & 2.82 & $3.574(3)$ & 135.4 \\
\hline $\mathrm{C} 4-\mathrm{H} 4 \mathrm{~B} \ldots l_{5}^{d}$ & 0.97 & 2.68 & $3.500(3)$ & 142.6 \\
\hline $\mathrm{C} 7-\mathrm{H} 7 \mathrm{~B} \ldots \mathrm{Cl} l_{1}^{e}$ & 0.97 & 2.95 & $3.525(3)$ & 119.0 \\
\hline $\mathrm{C} 7-\mathrm{H} 7 \mathrm{~A} \ldots C l_{5}^{c}$ & 0.97 & 2.93 & $3.573(3)$ & 124.6 \\
\hline $\mathrm{C} 2-\mathrm{H} 2 \mathrm{~B} \ldots \mathrm{Cl} l_{2}^{a}$ & 0.97 & 2.91 & $3.629(3)$ & 132.2 \\
\hline $\mathrm{C} 6-\mathrm{H} 6 \mathrm{~A} \ldots C l_{4}^{e}$ & 0.97 & 2.93 & $3.678(3)$ & 134.3 \\
\hline $\mathrm{C} 6-\mathrm{H} 6 \mathrm{~B} \ldots \mathrm{Cl} l_{1}$ & 0.97 & 2.94 & $3.618(3)$ & 128.2 \\
\hline $\mathrm{C} 7-\mathrm{H} 7 \mathrm{~B} \ldots C l_{6}^{d}$ & 0.97 & 2.83 & $3.632(3)$ & 141.0 \\
\hline
\end{tabular}

${ }^{\mathrm{a}}$ Code of symmetry : $-\mathrm{x},-\mathrm{y},-\mathrm{z}$

${ }^{\mathrm{b}}$ Code of symmetry : $\mathrm{x}-1 / 2,-\mathrm{y}-1 / 2, \mathrm{z}-1 / 2$

${ }^{c}$ Code of symmetry : $\mathrm{x}-1 / 2,-\mathrm{y}-1 / 2, \mathrm{z}-1 / 2 \quad{ }^{\mathrm{d}}$ Code of symmetry : $-\mathrm{x},-\mathrm{y},-\mathrm{z}$

${ }^{\mathrm{e}}$ Code of symmetry : $-\mathrm{x},-\mathrm{y},-\mathrm{z}$

${ }^{\mathrm{f}}$ Code of symmetry : $-\mathrm{x}+1 / 2, \mathrm{y}+1 / 2,-\mathrm{z}+1 / 2$ 
Table 3: The enrichment ratio of contacts highlights if interactions are over or underrepresented in the crystal as compared to equiprobable contacts occurring with the same chemical content on the surface

\begin{tabular}{cccccccc}
\hline Enrichement & $\mathrm{Hn} / \mathrm{o}$ & $\mathrm{C}$ & $\mathrm{N}$ & $\mathrm{O}$ & $\mathrm{Cl}$ & $\mathrm{Cd}$ & $\mathrm{Hc}$ \\
$\mathrm{Hn} / \mathrm{o}$ & 0.25 & & & & & & \\
$\mathrm{C}$ & 0.18 & 11.34 & & & & & \\
$\mathrm{~N}$ & 0.00 & 7.46 & 0.00 & & & & \\
$\mathrm{O}$ & 0.00 & 0.00 & 0.00 & 0.00 & & & \\
$\mathrm{Cl}$ & $\mathbf{1 . 9 2}$ & 0.30 & 1.91 & 0.00 & 0.35 & & \\
$\mathrm{Cd}$ & 0.13 & 0.00 & 0.00 & 0.00 & 1.72 & 0.76 & \\
$\mathrm{Hc}$ & $\mathbf{0 . 5 3}$ & 0.44 & 0.00 & 4.01 & $\mathbf{1 . 5 3}$ & 0.31 & 0.71 \\
Surface \% & 16.37 & 4.54 & 0.44 & 0.82 & 44.26 & 7.99 & 25.58 \\
\hline
\end{tabular}


Table 4: Scavenging activity of $\left[\mathrm{Cd}_{4} \mathrm{Cl}_{12}\left(\mathrm{H}_{2} \mathrm{O}\right)_{2}\right] \mathrm{n}\left(\mathrm{C}_{10} \mathrm{~N}_{4} \mathrm{H}_{28}\right)$ n. The data are reported as mean \pm standard deviation, $* * * p<0.001$ significantly different from the ascorbic acid

\begin{tabular}{|lc|}
\hline \multicolumn{1}{|c|}{ DPPH $(\mathrm{IC} 50 \mu \mathrm{g} / \mathrm{ml})$} & ABTS $(\mathrm{IC} 50 \mu \mathrm{g} / \mathrm{ml})$ \\
\hline $\left.\mathrm{Cd}_{4} \mathrm{Cl}_{12}\left(\mathrm{H}_{2} \mathrm{O}\right)_{2}\right] \mathrm{n}\left(\mathrm{C}_{10} \mathrm{~N}_{4} \mathrm{H}_{28}\right) \mathrm{n} 15.2 \pm 0.03 * * *$ & $36.3 \pm 0.004 * * *$ \\
Ascorbic acid $0.14 \pm 0.007$ & $0.532 \pm 0.006$ \\
\hline
\end{tabular}


Table 5: Zone of inhibition (mm), of $\left[\mathrm{Cd}_{4} \mathrm{Cl}_{12}(\mathrm{H} 2 \mathrm{O})_{2}\right] \mathrm{n}\left(\mathrm{C}_{10} \mathrm{~N}_{4} \mathrm{H}_{28}\right) \mathrm{n}$ against bacteria. The data are reported as mean \pm standard deviation

\begin{tabular}{|llr|}
\hline \multicolumn{1}{|c|}{ Bacteria } & \multicolumn{1}{c|}{ Zone of inhibition (mm) } \\
\hline \multicolumn{1}{|c|}{$\left[\mathrm{Cd}_{4} \mathrm{Cl}_{12}\left(\mathrm{H}_{2} \mathrm{O}\right)_{2}\right] \mathrm{n}\left(\mathrm{C}_{10} \mathrm{~N}_{4} \mathrm{H}_{28}\right) \mathrm{n}$} & Streptomycine \\
\hline Pseudomonas aeruginosa SH 38 & $6 * * *$ & 15 \\
Escherichia coli JW 1772 & $24.5 \pm 0.5^{* *}$ & 20 \\
Salmonella typhimurium ATCC 14028 & $15 \pm 0.3^{* * *}$ & 26 \\
Staphylococcus aureus NCTC 6571 & $7 \pm 0.5^{* * *}$ & 29 \\
Enterococcus faecalis ATCC 29212 & $6 \pm 0.5^{* * *}$ & 25 \\
& & \\
\hline
\end{tabular}

$* * \mathrm{p}<0.01$ and $* * * \mathrm{p}<0.001$ significantly different from the Streptomycine inhibition zone 


\section{Supplementary}

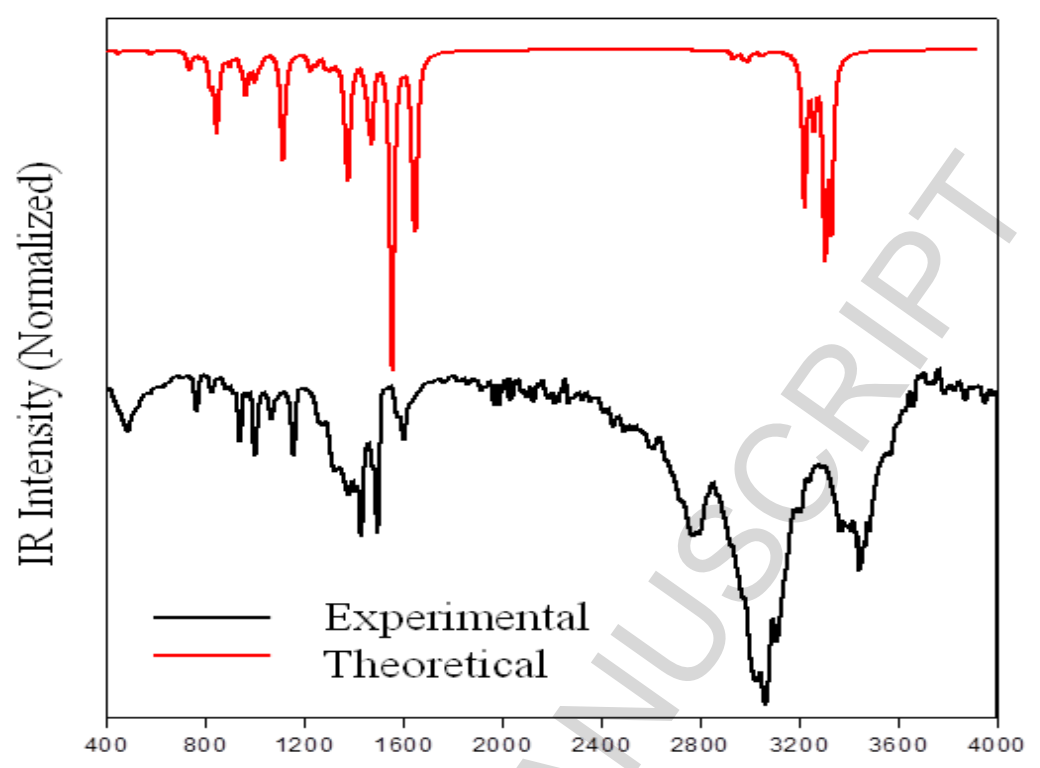

S.1: Simulated and experimental IR spectrum of $\left[\mathrm{Cd}_{4} \mathrm{Cl}_{12}\left(\mathrm{H}_{2} \mathrm{O}\right)_{2}\right] n\left(\mathrm{C}_{10} \mathrm{~N}_{4} \mathrm{H}_{28}\right)$ n.

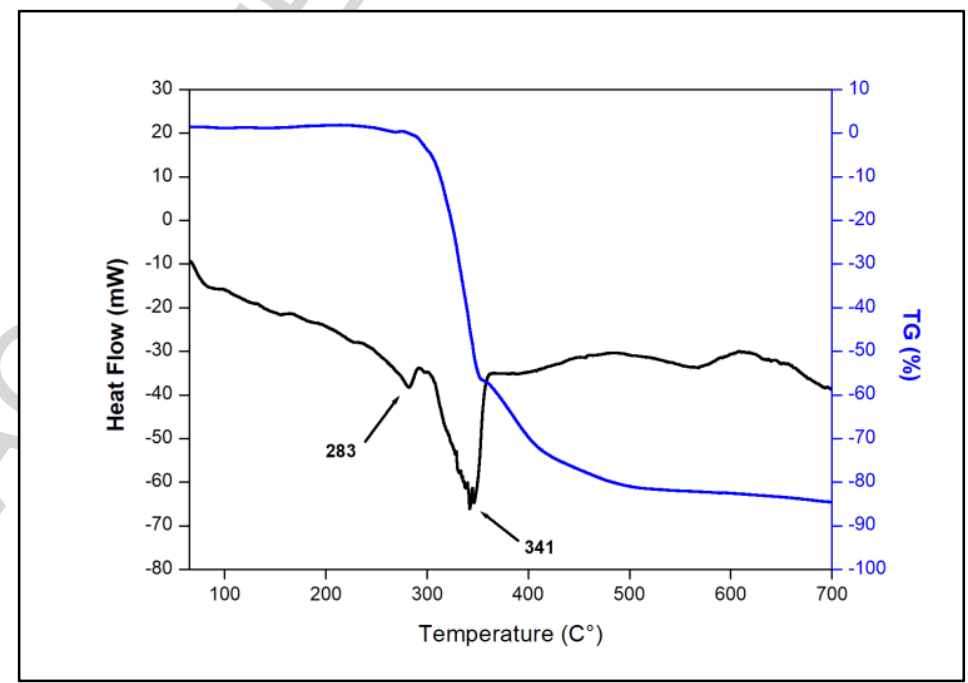

S.2: TG-DTA heating of $\left[\mathrm{Cd}_{4} \mathrm{Cl}_{12}\left(\mathrm{H}_{2} \mathrm{O}\right)_{2}\right] n\left(\mathrm{C}_{10} \mathrm{~N}_{4} \mathrm{H}_{28}\right) n$ 


\section{Computational details}

It is well known that the vibrational modes of the inorganic entities occur at low frequencies ranges (below $400 \mathrm{~cm}^{-1}$ ) which not considered in our IR experimental technique. That's why, in our theoretical study, we have chosen to facilitate the calculations and consider only the organic part. Standard atomic positions of one $\left[\mathrm{C}_{10} \mathrm{~N}_{4} \mathrm{H}_{28}\right]^{4+}$ cation are taken from the $\mathrm{X}$-Ray diffraction data. Complete geometry optimization and normal modes calculations are performed by the DFT theory implemented in the Gaussian 09 software and using B3LYP functional and $6-311 \mathrm{G}^{* *}$ basis set. The absence of imaginary frequencies was checked and a scale factor (0.972) is used. 

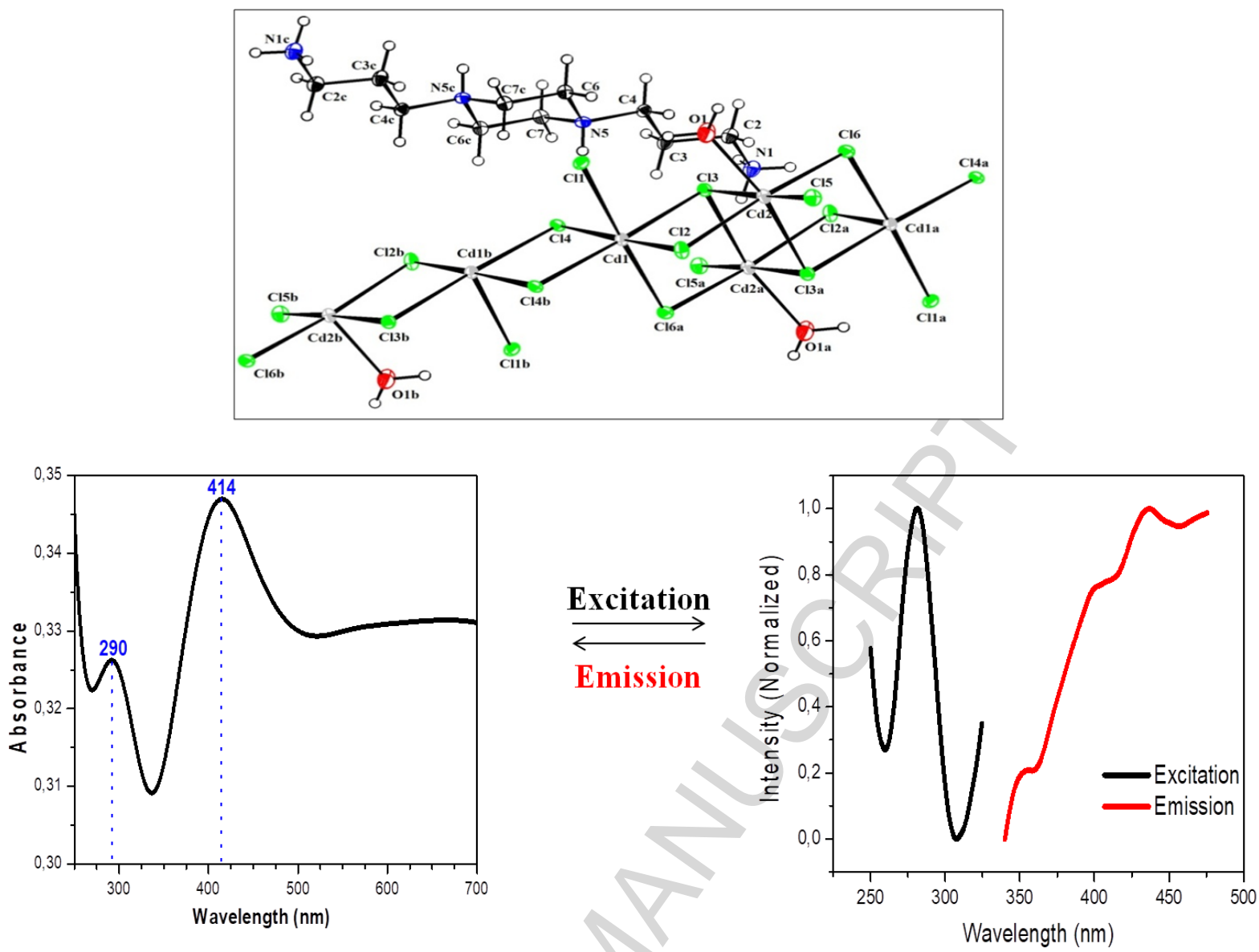

Graphical abstract 


\section{Highlights}

- Synthesis of new organic-inorganic hybrid material $\left[\mathrm{Cd}_{4} \mathrm{Cl}_{12}\left(\mathrm{H}_{2} \mathrm{O}\right)_{2}\right] \mathrm{n}\left(\mathrm{C}_{10} \mathrm{~N}_{4} \mathrm{H}_{28}\right) \mathrm{n}$.

- The determination of crystallographic coordinates by XRD on a crystal.

- Vibrational properties were studied by Infrared Spectroscopy.

- The behavior of this new compound is a semiconductor been proved by the study of optical absorption.

- The bioassay results showed that the structure exhibits significant antibacterial activity.

- Thermal properties of the crystal were analyzed by TG-DTA. 